\title{
Extreme intensity of fluid-rock interaction during extensive intraplate volcanism
}

\section{Beier, Christoph}

2019-07-15

Beier , C , Bach , W , Busch , A V , Genske , F S , Hübscher , C \& Krumm , S H 2019 , ' Extreme intensity of fluid-rock interaction during extensive intraplate volcanism ' , Geochimica et Cosmochimica Acta , vol. 257 , pp. 26-48 . https://doi.org/10.1016/j.gca.2019.04.017

http://hdl.handle.net/10138/329370

https://doi.org/10.1016/j.gca.2019.04.017

acceptedVersion

Downloaded from Helda, University of Helsinki institutional repository.

This is an electronic reprint of the original article.

This reprint may differ from the original in pagination and typographic detail.

Please cite the original version. 


\section{Accepted Manuscript}

Extreme intensity of fluid-rock interaction during extensive intraplate volcanism

Christoph Beier, Wolfgang Bach, Alexander V. Busch, Felix S. Genske, Christian Hübscher, Stefan H. Krumm

PII:

S0016-7037(19)30243-1

DOI: https://doi.org/10.1016/j.gca.2019.04.017

Reference:

GCA 11212

To appear in:

Geochimica et Cosmochimica Acta

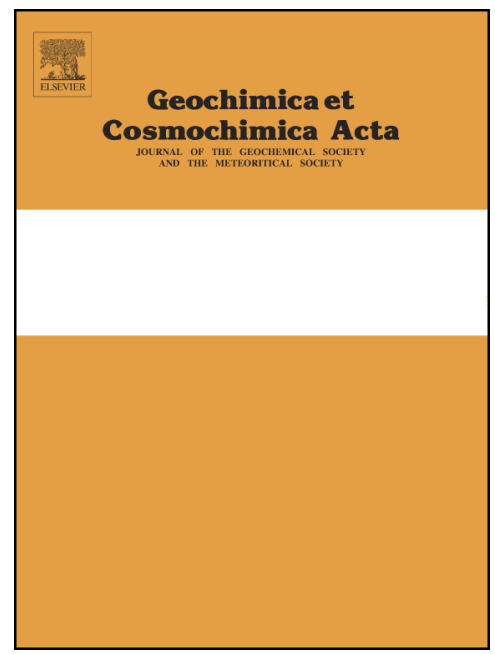

Received Date: $\quad 15$ September 2018

Revised Date: $\quad 16$ April 2019

Accepted Date: $\quad 17$ April 2019

Please cite this article as: Beier, C., Bach, W., Busch, A.V., Genske, F.S., Hübscher, C., Krumm, S.H., Extreme intensity of fluid-rock interaction during extensive intraplate volcanism, Geochimica et Cosmochimica Acta (2019), doi: https://doi.org/10.1016/j.gca.2019.04.017

This is a PDF file of an unedited manuscript that has been accepted for publication. As a service to our customers we are providing this early version of the manuscript. The manuscript will undergo copyediting, typesetting, and review of the resulting proof before it is published in its final form. Please note that during the production process errors may be discovered which could affect the content, and all legal disclaimers that apply to the journal pertain. 


\title{
Extreme intensity of fluid-rock interaction during extensive intraplate volcanism
}

Christoph Beier ${ }^{1,2^{*}}$, Wolfgang Bach $^{3,4}$, Alexander V. Busch ${ }^{3,4}$, Felix S. Genske ${ }^{5}$, Christian Hübscher $^{6}$, Stefan H. Krumm ${ }^{2}$

${ }^{1}$ Department of Geosciences and Geography, University of Helsinki, P.O. Box 64, FIN-00014

Helsinki, Finland

${ }^{2}$ GeoZentrum Nordbayern, Friedrich-Alexander Universität Erlangen-Nürnberg, Schloßgarten 5, D-91054 Erlangen

${ }^{3}$ MARUM, Zentrum für Marine Umweltwissenschaften, Universität Bremen, Germany

${ }^{4}$ Fachbereich Geowissenschaften, Universität Bremen, Klagenfurter Str. 2, D-28359 Bremen, Germany

${ }^{5}$ Institut für Mineralogie, Westfälische Wilhelms-Universität Münster, Germany

${ }^{6}$ Institut für Geophysik Universität Hamburg Bundesstrasse 55, D-20146 Hamburg

*corresponding author, Email: christoph.beier@helsinki.fi, phone: +358/2941-51718

\begin{abstract}
The initial formation and temporal evolution of large igneous plateaus and the extent to which these large enigmatic igneous features impact on their immediate and distant ecological surrounding remains a matter of active research. The compositional variability in large igneous provinces has mainly been attributed to changes in the melting regime and shallow crustal processes and commonly range from depleted tholeiitic basaltic to enriched alkaline lavas. Large igneous provinces erupted in the submarine environment however, may also experience intense hydrothermal alteration during their formation resulting from an increased exchange between seawater and the erupting lavas during their eruptive history. The submarine Azores Plateau in the Central Northern Atlantic has generally been treated to represent such large igneous province formed since $\sim 10$ Ma by widespread volcanism and the unique tectonic regime which results in large fault systems exposing the erupted lavas. Here, we present new seismic, petrological and major element, trace element and isotope geochemical data from a $\sim 1000 \mathrm{~m}$ stratigraphic section of submarine lavas exposed at the
\end{abstract}


western Princessa Alice bank. The 22 samples recovered from the near-vertical rift wall provide evidence for intense water-rock exchange not observed anywhere in oceanic crust sampled to date. Fluid-immobile incompatible trace elements show that the samples formed from higher degrees of partial melting of a mantle source that is less enriched than the source that gives rise to the islands today. The extents of melting today are very small, implying a change in melting regime since initial formation of the Princessa Alice Plateau basalts that correspond to a melting anomaly in the Azores. Our observations indicate that the extreme levels of alteration may result from a combination of intensified magmatic activity during initial formation of the Azores Plateau and the tectonic regime providing pathways for the fluids. Our results impact on the interpretation of shallow level crustal magmatic processes, in which the contribution of crustal sources to the ascending melt may be different to what had previously been suggested. We propose that hydrothermal alteration during submarine igneous plateau forming events may drastically change the compositions of the igneous crust. The associated elemental and isotopic exchange between the oceanic crust and hydrosphere may substantially change the chemical fluxes between oceans and crust during the emplacement of oceanic plateaus.

Keywords: large igneous province; Azores Plateau; water-rock reactions; ocean-crust exchange 


\section{INTRODUCTION}

The emplacement, formation and modification of lavas erupted in large igneous provinces and their impact on the marine environment and atmosphere remain a matter of active debate (Bond and Wignall, 2014; Bryan and Ernst, 2008; Coffin and Eldholm, 1992; Coffin and Eldholm, 1994; Courtillot and Renne, 2003; Korenaga, 2005; Neal et al., 2002). The gasses released during formation of subaerial large igneous provinces may lead to sulfuric acid aerosol particles in the atmosphere resulting in reduced levels of sunlight and volcanic winter' (Self, 2006; Self and Blake, 2008; Self et al., 2008), whereas submarine large igneous provinces have been associated with global anoxia events (Erba, 1994; Larson and Erba, 1999; Tarduno et al., 1991; Tejada et al., 2012). The eruption of large volumes of magma within relatively short time-scales of few million years, e.g., at the Ontong Java, Shatsky, Manihiki and Hikurangi Oceanic Plateaus is often followed by the eruption of smaller amounts of magma along an age-progressive seamount chain (Bryan and Ernst, 2008; Coffin and Eldholm, 1992; Kerr, 2014; Sager et al., 2016; Sano et al., 2012). The main geochemical changes that have been associated with the eruption of large igneous provinces have been attributed to changes in the melting regime (Coffin and Eldholm, 1994; Sharkov et al., 2017). The progressive change from least-enriched, tholeiitic lavas formed from the initial high degrees of partial melting to alkaline, enriched lavas has been attributed to variations in the melting and melt ascent regime (Hirschmann et al., 1999; Hirschmann et al., 1998; Johnson et al., 2005; Ridley and Richards, 2010; Sharkov et al., 2017). Submarine large igneous provinces may however also experience substantial geochemical modification from exchange between crust and convecting seawater similar to mid-ocean ridges (Alt, 1997; Alt et al., 1986; Alt et al., 1996; Alt and Teagle, 2000; Bach et al., 2003; Elderfield and Schultz, 1996; German and Parson, 1998; Harris et al., 2017; Michael, 1999; Staudigel, 2003). Due to the scarce availability of samples from deeper stratigraphic levels of oceanic large igneous provinces, the geochemical evolution and subsequent alteration of oceanic plateaus has been mainly inferred from those plateaus drilled during Ocean Drilling Program (ODP) and International Ocean Drilling Program (IODP) and few dredging expeditions (Fitton and Godard, 2004; Frey et al., 2000; Ingle et al., 2007; Mahoney et al., 1995; Mahoney and Spencer, 1991; Mahoney et al., 1993; Neal et al., 2002; Neal et al., 1997; Sager et al., 2016).

A substantial volume of the submarine Azores archipelago has been emplaced during arrival of a melting anomaly at $\sim 10 \mathrm{Ma}$ (Beier et al., 2015; Cannat et al., 1999; Gente et al., 2003; O’Neill and Sigloch, 2018; Vogt and Jung, 2018) as a result of increased volatile contents in the upper mantle (Asimow et al., 2004; Beier et al., 2012; Metrich et al., 2014; 
Rose-Koga et al., 2017). Magmatism in the Azores has also been substantially influenced by tectonic activity with several movements of the active, slow-spreading plate boundary from south to north (Bastos et al., 1996; Beier et al., 2008; Fernandes et al., 2006; Hildenbrand et al., 2008; Krause and Watkins, 1970; Luis and Miranda, 2008; Marques et al., 2013; Miranda et al., 2018; Romer et al., 2018; Vogt and Jung, 2018). This change in tectonic regime has resulted in numerous, relatively steep fault scarps cutting through the older, plateau-building edifices and allowing stratigraphic sampling of the lavas erupted during the early plateauforming stages.

Here, we present a petrological and geochemical dataset of 22 samples from a stratigraphic profile from the western Princessa Alice bank in the Azores. Seismic imagery displays a sequence of sub-horizontal lava flows exposed on the fault scarp. The immobile and incompatible trace element ratios (e.g., $\left.\mathrm{Nb} / \mathrm{Zr},(\mathrm{Ce} / \mathrm{Yb})_{\mathrm{N}}, \mathrm{Tb} / \mathrm{Yb}\right)$ however, display a distinct variability best explained by relatively high degrees of partial melting of enriched mantle, which we interpret to result from the initial arrival of a melting anomaly underneath the Azores in agreement with geophysical and geodynamic models. Our petrological and geochemical data reveal that the samples display the highest intensity of water-rock interaction yet observed in oceanic hydrothermal systems making this stratigraphic section an endmember amongst altered ocean crust globally. The samples are exclusively altered to greenschist-facies assemblages in the deepest sections and chlorite/smectite-quartz rocks in the topmost part of the section. We interpret the extreme degree and variability of rock alteration to result from a continuous, possibly several Ma lasting magmatic activity during the emplacement of the plateau and the syn-magmatic tectonic activity providing fluid pathways in which the older lavas on the basis of the profile have been subjected to repeated episodes of hydrothermal seawater circulation and associated rock alteration. The compositions of the lavas at Princessa Alice bank indicate that the basement of submarine large igneous provinces may be substantially changed by this intense hydrothermal alteration. These observations may also be applicable to other oceanic plateaus displaying syn-magmatic tectonic activity and will significantly impact on the overall composition of samples from oceanic plateaus.

\section{GeOlogical SETting}

The Azores Plateau has been separated into a larger eastern and smaller wester part separated by the slow-spreading mid-Atlantic ridge (MAR; Fig. 1). Seismic results indicate a crustal thickness of almost $14 \mathrm{~km}$ for the plateau (Escartín et al., 2001). The eastern Azores Plateau 
consists of the Terceira Rift axis in the North, an ultraslow spreading rift axis (Marques et al., 2013; Vogt and Jung, 2018; Vogt and Jung, 2004) which marks the recent plate boundary between the Eurasian and African plates. South of the islands of Faial and Pico, the submarine Princessa Alice bank is an area of anomalous shallow water depth reaching up to 1000 meters below sea level (mbsl) and almost $3 \mathrm{~km}$ 's above the surrounding normal seafloor. Geodynamic models, the bathymetric anomaly and age dating suggest that much of the initial platform building stage forming Princessa Alice bank occurred by the arrival of a melting anomaly between 10 and $6 \mathrm{Ma}$ (Beier et al., 2015; Cannat et al., 1999; Gente et al., 2003; Luis et al., 1994) accompanied and followed by magma ascent along structural features related to the Eurasian-African plate boundaries that made several northward jumps to their current position at the Terceira rift axis (Krause and Watkins, 1970). These structural features formed several steep fault crevices and wide basins at Princessa Alice bank, some of these basins up to $17-20 \mathrm{~km}$ wide suggesting either relatively fast rates or a long duration of rifting. Basins on the western border of Princessa Alice bank commonly lie on continuations of fracture zones along the MAR. Dredged lavas in the vicinity of western Princessa Alice bank are tholeiitic in composition (Beier et al., 2015) while lavas to the North of Princessa Alice bank at Condor Rift are younger at $\sim 1 \mathrm{Ma}$ and commonly alkaline (Romer et al., 2018).

\section{METHODS}

The seismic data were obtained during cruise M113/1 with the German RV Meteor (Hübscher et al., 2016) and procedures are described in more detail in Romer et al. (2018). The rock samples were taken during a subsequent cruise M128 (June/July 2016) by Remotely Operated Vehicle (ROV) MARUM Quest 4000m from the MARUM Zentrum für Marine Umweltwissenschaften, Bremen, Germany (Beier et al., 2018a). During the two dives 810_ROV and 824_ROV along a nearly vertical wall from 2,484 to 1,439 mbsl, 22 rock samples were preferentially selected from outcropping lithologies with depth intervals ranging from 20 to $180 \mathrm{~m}$ (Table 1). Dive 810_ROV started at 2,484 mbsl and finished at 1,713 mbsl while the overlapping dive 824_ROV commenced at 1,980 mbsl and finished at 1,439 mbsl. The ROV images reveal a relatively thick sediment coverage of most outcropping lavas (Fig. 2), however, dykes and pillows occur in the lower part of the profile. The samples have been labeled using an International Geo Sample Number (IGSN) using the System of Earth Samples Registration (SESAR; Table 1, supplemental Table A1 and A2).

\section{Multi-channel seismic data}


The high-resolution reflection seismic system consisted of four GI-Gun as the seismic source array and a 144-channel digital streamer cable with an active length of $600 \mathrm{~m}$. The GIGuns were released every 10 seconds in "true GI mode" with generator and injector volumes of 45 and $105 \mathrm{in}^{3}$, respectively, producing a signal of $100 \mathrm{~Hz}$ dominant frequency. Data processing included frequency filtering $(15-350 \mathrm{~Hz})$, gain, velocity analysis (every $50 \mathrm{CMPs}$ ), NMO-correction, coherency filtering, stacking, time-migration, bandpass, white noise removal, dip filtering and fx-deconvolution. For an overview of the method see Hübscher and Gohl (2014).

\section{Thin section analysis}

The samples were cut on board RV Meteor and selected for thin section and geochemical analyses. Twenty thin sections were subsequently prepared for Field Emission Scanning Electron Microscope (FE-SEM), electron microprobe analysis (EMPA) and laser ablation inductively coupled plasma mass spectrometry (LA-ICP-MS). All thin sections were analyzed using equipment at the University of Bremen, Germany. We used a Zeiss SUPRA 40 SEM equipped with a field emission electron source and Gemini Optics. All images were performed on carbon coated thin sections using and acceleration voltage of $15 \mathrm{kV}$. Electron microprobe analyses were performed using a Cameca SX 100 at the University of Bremen analyzing the major elements $\mathrm{SiO}_{2}, \mathrm{TiO}_{2}, \mathrm{Al}_{2} \mathrm{O}_{3}, \mathrm{FeO}, \mathrm{MnO}, \mathrm{Cr}_{2} \mathrm{O}_{3}, \mathrm{MgO}, \mathrm{CaO}, \mathrm{Na}_{2} \mathrm{O}$ and $\mathrm{K}_{2} \mathrm{O}$. The instrument was operated at $15 \mathrm{kV}$ and $15 \mathrm{nA}$ and a fully focused beam for most minerals. For plagioclase, the instrument was operated at $8 \mathrm{kV}, 15 \mathrm{nA}$ and a defocused beam at $5 \mu \mathrm{m}$.

For mineral trace element analyses of epidote and clinopyroxenes nine thin sections were analyzed using a UP193ss New Wave $^{\mathrm{TM}}$ laser system on a Thermo ${ }^{\mathrm{TM}}$ Element 2. Calcium and Si contents from the EPMA analysis were used as internal standards. An argonhelium mixture was used as carrier gas, $100 \mu \mathrm{m}$ spots were measured with a $10 \mathrm{~Hz}$ repetition rate. In a few cases, epidote analyses were performed with $50 \mu \mathrm{m}$ spot sizes. Maximum peak measuring times were $60 \mathrm{~s}$, backgrounds were measured for $30 \mathrm{~s}$, respectively. To ensure accuracy and reproducibility, USGS glasses BHVO-2G and BCR-2G were periodically analyzed. The instrument was calibrated using NIST-610 which was also frequently analyzed. The data were corrected using GeoPro ${ }^{\mathrm{TM}}$ by CETAC. 


\section{Geochemical analysis}

Bulk whole rock analyses from all samples were performed using X-ray fluorescence (XRF) and LA-ICP-MS on glass beads at the Westfälische Wilhelms-Universität Münster, Germany (Table 1, supplemental Table A3). For the XRF major element analyses $500 \mathrm{mg}$ of fineground whole rock sample powder were mixed with $4 \mathrm{~g}$ lithiumtetraborate-metaborate (12:22) and ammonium-iodide. The mixture was molten into homogenous glass beads. The glasses were analyzed using a Panalytical ${ }^{\mathrm{TM}}$ Epsilon 3 energy-dispersive XRF. The international rock reference materials BHVO-2 and BCR-2 were fused according to the same protocol and were analyzed ten times each, to ensure precision and accuracy (supplemental Table A3). For the trace elements analysis, the samples and both reference materials were prepared using the method described in Stoll et al. (2008). The glass samples were then ablated with a spot size of $80 \mu \mathrm{m}$, using a $193 \mathrm{~nm}$ ArF excimer laser (Analyte G2, Photon Machines) at a repetition

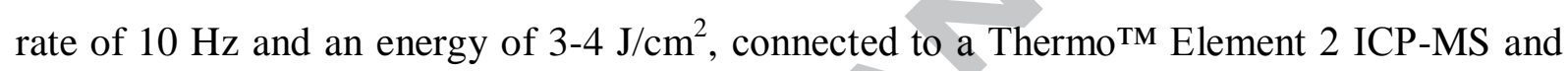
using NIST-610 for calibration. We present here the average of 5 to 8 individual spots per sample. International glass standards BHVO-2G and BCR-2G were analyzed every 10-12 samples to ensure precision and accuracy. The data were processed using the Glitter software package (Van Achterbergh et al., 2001).

Total inorganic carbon (TIC) contents were measured by adding $12.5 \% \mathrm{HCl}$ to $50-100$ mg of sample powder. The analyses were performed on a Leco CS200 at the University of Bremen. The $\mathrm{H}_{2} \mathrm{O}$ contents were calculated assuming that the remaining portion of the loss on ignition (LOI) after subtracting $\mathrm{CO}_{2}$ contents would be $\mathrm{H}_{2} \mathrm{O}$. We observe a broad correlation with $\mathrm{MgO}$ whole rock contents implying that this approach may be valid.

The ${ }^{87} \mathrm{Sr} /{ }^{86} \mathrm{Sr}$ isotope ratios of the whole rock samples, three carbonate crusts and three epidote separates were analyzed using a Thermo Finnigan Triton TIMS at the Westfälische Wilhelms-Universität Münster (WWU, Table 1, supplemental Table A2). The rock samples were dissolved using a mixture of concentrated, double-distilled $\mathrm{HF}$ and $\mathrm{HNO}_{3}$. The carbonate samples were dissolved with $6 \mathrm{~N} \mathrm{HCl}$ and the epidote separates were leached with $3 \mathrm{~N} \mathrm{HCl}$ at room temperature to remove fine intergrowths of calcite, prior to dissolution using concentrated $\mathrm{HF}$ and $\mathrm{HNO}_{3}$. Both epidotes and their leachates were analyzed for the $\mathrm{Sr}$ isotopic composition. The $\mathrm{Sr}$ was separated using cation exchange procedures described in Pin and Zalduegui (1997). Reference materials BHVO-2 and BCR-2 give ${ }^{87} \mathrm{Sr} /{ }^{86} \mathrm{Sr}=$ $0.703487 \pm 19$ (2 S.E.) and $0.705019 \pm 19$ (2 S.E.), which are in agreement with literature data. The ${ }^{87} \mathrm{Sr} /{ }^{86} \mathrm{Sr}$ are normalized to ${ }^{88} \mathrm{Sr} /{ }^{86} \mathrm{Sr}=8.37521$ using the exponential mass 
fractionation law. All data were normalized to NBS987 of 0.710247 (Weis et al., 2006), which was measured periodically throughout the course of this study.

The stable $\delta^{18} \mathrm{O}_{\mathrm{V} \text {-SMOW }}$ isotope ratios of calcites in veins were determined using a Finnigan MAT 251 gas isotope mass spectrometer combined with a Kiel I automated carbonate preparation device at MARUM Zentrum für Marine Umweltwissenschaften, Bremen, Germany. The samples were calibrated against a natural sourced carbonic acid. The in-house Solnhofen limestone standard was calibrated against NBS 10 and resulted in a relative standard deviation of $0.5 \%$ for $\delta^{18} \mathrm{O}_{\mathrm{V} \text {-SMOW }}$ and $\delta^{13} \mathrm{C}$ considering the much lower standard concentrations.

Two samples of separated quartz veins and four epidote veins were analyzed for their $\delta^{18} \mathrm{O}_{\mathrm{V}-\mathrm{SMOW}}$ isotope composition using the method described in more detail in Genske et al. (2013). Three out of the four epidote veins were pre-leached using $2 \mathrm{M} \mathrm{HCl}$ to prevent mixed analyses conditioned by the fine intergrowths of calcite and epidote (supplemental Table A2). The mineral separates reacted more than 12 hours with the acid and were processed through a repeated sequence (five times) of washing with MilliQ-water and centrifugation. The mineral standards Granat UWG and Quarz GEE give a standard deviation of $0.20 \%$ and up to $0.23 \%$ o over an analytical period of three days.

\section{RESULTS}

The samples obtained during M128 Azores Plateau will be compared to those dredged during RV Poseidon cruise POS286 presented in Beier et al. (2015). In addition, we use samples discussed in Romer et al. (2018) from Condor Rift at the northern border of Princessa Alice bank for geochemical comparison due to their geological and geographical proximity (Fig. 1). 


\section{SEISMIC IMAGERY}

The seismic profile presented in Fig. 2 is $\sim 7 \mathrm{~km}$ long and covers the more than $1600 \mathrm{~m}$ high rift wall of a basin NW of the western Princess Alice Bank. The seismic units across the flank consist of sub-parallel seismic units of approximately similar thickness (P1-P6). Internal reflections dip towards and terminate against the rift wall with the exception of P1 which is intercalated with the parallel to sub-parallel basin fill deposits (PS1). Units P7 and P8 have a more conical shape. All units display similar internal reflection patterns implying that the units consist of comparable lithologies. We did not observe a clear base at unit P1 as opposed to all other, overlying younger units.

\section{Petrology}

All analyzed samples are highly altered, aphanitic lavas. The samples contain mineral assemblages typically observed in highly altered, greenschist-facies metabasaltic rocks (Fig. 3) but the precursor igneous assemblage likely consisted of fine to medium grained plagioclase and clinopyroxene phenocrysts (Fig. 4d). The prevailing alteration minerals includes illite and a number of unclassified clay minerals, quartz, chlorite, actinolite, calcite, hematite and epidote in varying proportions throughout the profile (Fig. 3).

Only sample IEAZO1122 (810_ROV-10) contains idiomorphic to hypidiomorphic small $(0.5-1 \mathrm{~mm})$ primary clinopyroxene crystals (Fig. 4). At lower stages of alteration, primary clinopyroxenes are replaced by chlorite along veins and cracks and display actinolite rims (Fig. 4). The primary clinopyroxenes are classified as Mg-rich augites based on their composition (supplemental Table A1).

The amount of plagioclase varies inversely with the overall amount of calcite, epidote and quartz veins in the samples and is absent in the uppermost part of the profile at water depth <1,500 mbsl (Fig. 4). Plagioclase occurs intersertal and subophitic but is frequently replaced by chlorite and quartz in the upper part of the profile. The amount and degree of alteration of the plagioclase varies systematically throughout the profile. In the lowermost part of the profile $(>2,400 \mathrm{mbsl})$, plagioclase is partly replaced by epidote. Plagioclase crystals generally display a complex decay to albite-rich rims, epidote, actinolite, chlorite and minor quartz. Only sample IEAZO1120 (810_ROV-08) contains relative An-rich crystals (An = 5575), which may be indicative for relatively lower degrees of alteration as opposed to all other samples in the profile (Fig. 3 and 4).

Hematite, calcite and quartz occur in all samples (supplemental Table A1). Chlorite and clay minerals also occur commonly but chlorite contents increase up to $50 \%$ at shallower 
water depth $(<1,600 \mathrm{mbsl}$; Fig. 3). In contrast, epidote is most abundant in the lowermost section (both replacive and in veins) and decreases in abundance up-section; it is absent in the topmost $300 \mathrm{~m}$ of the profile (Fig. 4). Chlorites appear microcrystalline as intergrowths with quartz, epidote and actinolite or as concentric fillings or fine veins in vesicles or replacing clinopyroxene. Iron numbers $(\mathrm{Fe} \#=\mathrm{Fe} /(\mathrm{Fe}+\mathrm{Mg}))$ range up to 0.5 with an average at 0.39 . Based on the classification by Bayliss (1975) the chlorites are characterized as clinochlore (supplemental Table A1). Temperatures calculated using averaged chlorite $\mathrm{Al}^{\mathrm{IV}}$ contents yield values of $216-293^{\circ} \mathrm{C}$ with an average of $253^{\circ} \mathrm{C}$ (De Caritat et al., 1993).

Calcite and quartz commonly occur in veins; samples IEAZO1115 and IEAZO1122 are crosscut by veins of quartz and epidote (Fig. 4). Epidote is common in the lower part of the profile (below 1,667 mbsl) and occurs as fibrous to acicular grains in veins or as microcrystalline patches with quartz, actinolite and chlorite. Actinolite is rare in this assemblage and limited to bottom-part of the section below 1,806 mbsl (Fig. 3). Titanite, anatase and ilmenite were determined as the main Fe-Ti phases. Titanite is secondary and occurs from 2,484 to 1,700 mbsl. At shallower depth, anatase occurs as the main secondary Ti-phase, whereas ilmenite was only observed in sample IEAZO1157. Illite occurs as a product of epidote and plagioclase alteration in the shallower parts of the profile to water depths of $\sim 1,800$ mbsl. Calcite occurs at greater water depths as infill in epidote-quartz veins. At water depths of 2,000 mbsl (IEAZO1120 and IEAZO1122; Fig. 3) calcite is the most abundant vein mineral (Fig. 4).

Sample IEAZO1124 almost exclusively consists of quartz-veins in agreement with the elevated $\mathrm{SiO}_{2}$ contents of $\sim 80 \mathrm{wt} . \%$ (Table 1). In the upper part of the profile at shallower water depth of $\sim 1,750$ mbsl (IEAZO1160) quartz is the most common vein mineral (Fig. 4).

\section{GEOCHEMISTRY}

Lavas from the southwestern Princessa Alice bank generally display elevated losses on ignition (LOIs) exceeding 1 wt.\% reaching as high as almost 14 wt.\% (IEAZO1162) in agreement with their alteration mineral assemblage and comparable to some of the published samples from Princessa Alice Bank (Beier et al., 2015). Hence, we will distinguish between elements sensitive to alteration and those that may reflect the primary melting and source signal (see also discussion below).

Generally, the lavas are the least alkaline observed in the Azores; however, due to the mobility of $\mathrm{Na}_{2} \mathrm{O}$ and $\mathrm{K}_{2} \mathrm{O}$ during alteration the degree of alkalinity of the western Princessa Alice bank is difficult to evaluate (Fig. 5). The lavas display $\mathrm{MgO}$ contents ranging from 14.2 
to $1.7 \mathrm{wt} . \%$ and $\mathrm{SiO}_{2}$ contents that range from 40.3 to $55.4 \mathrm{wt} . \%$; two lavas extend to $78 \mathrm{wt} . \%$ (IEAZO1124) and $33.1 \mathrm{wt} \%$ (IEAZO1160) $\mathrm{SiO}_{2}$, respectively. Note that sample IEAZO1124 contains a large quartz vein resulting in the elevated $\mathrm{SiO}_{2}$ contents (Fig. 5). Generally, the southwestern Princessa Alice bank lavas overlap with a number of published lavas from the same region (Beier et al., 2015) in that they display lower $\mathrm{TiO}_{2}$ and $\mathrm{K}_{2} \mathrm{O}$ and both lower and higher $\mathrm{Fe}_{2} \mathrm{O}_{3}{ }^{\mathrm{T}}, \mathrm{CaO}$ and $\mathrm{Na}_{2} \mathrm{O}$ compared to any of the lavas sampled from the islands (Fig. 5). Calculated $\mathrm{H}_{2} \mathrm{O}$ contents $\left(\mathrm{H}_{2} \mathrm{O}\right.$ [wt.\%] $=\mathrm{LOI}-\mathrm{CO}_{2}$ [wt.\%]) are positively correlated with $\mathrm{MgO}$ and display a broad negative trend with $\mathrm{CaO}$ (Fig. 5). We note here that oxidation of $\mathrm{FeO}$ to $\mathrm{Fe}_{2} \mathrm{O}_{3}$ could influence the calculated $\mathrm{H}_{2} \mathrm{O}$ contents, however, a lack of correlation between $\mathrm{Fe}_{2} \mathrm{O}_{3}{ }^{\mathrm{T}}$, $\mathrm{MgO}$ (Fig. 5) and $\mathrm{H}_{2} \mathrm{O}$ (not shown) suggests that this effect may be not be large enough to significantly impact on the calculated $\mathrm{H}_{2} \mathrm{O}$ contents. The $\mathrm{CO}_{2}$ contents are more elevated and display a larger range at higher $\mathrm{CaO}$.

The primitive mantle normalized trace element pattern are convex upward with a slight enrichment of the more incompatible trace elements and Light Rare Earth Elements (LREE), however, the degree of enrichment in our samples here is much less than that observed in the other Princessa Alice bank samples from Beier et al. (2015) and are less enriched than those from the islands of Pico and Faial (Fig. 6a). We also note that the Heavy Rare Earth Elements (HREE) are both less and more depleted than those from the other Azores samples (Beier et al., 2018b).

Source and melting sensitive, immobile trace element ratios, e.g., $\mathrm{Nb} / \mathrm{Zr}$ and $\mathrm{Ti} / \mathrm{Sm}$ (Fig. 7) overlap those of the other, published Azores lavas (Beier et al., 2018b), however, $(\mathrm{Ce} / \mathrm{Yb})_{\mathrm{N}}, \mathrm{Tb} / \mathrm{Yb}, \mathrm{Dy} / \mathrm{Yb}$ are significantly lower and $\mathrm{Sm} / \mathrm{Nd}$ ratios are higher than any of the other lavas from the Azores. The $\mathrm{Ce} / \mathrm{Ce} *\left(\mathrm{Ce} / \mathrm{Ce}^{*}=\mathrm{Ce}_{\mathrm{N}} /\left(\mathrm{La}_{\mathrm{N}} * \mathrm{Pr}_{\mathrm{N}}\right)^{0.5}\right)$ ratios range from 0.9 1.1 comparable with those from the nearby islands and other Azores samples but display much less range than those from the altered Pacific Louisville seamount chain lavas in which formation of chevkinites and bastnäsites may play a role as a result of the near surface exposure of the seamounts (Beier et al., 2011). At Princessa Alice bank there is no clear sense of correlation of $\mathrm{Ce} / \mathrm{Ce}$ * ratios with $\mathrm{H}_{2} \mathrm{O}$ or $\mathrm{CO}_{2}$ contents. Ratios of $\mathrm{Ce} / \mathrm{Pb}$ are extremely variable and straddle from 2 (IEAZO1115) to 167 (IEAZO1164) exceeding the range observed in the nearby islands. Ratios of $\mathrm{Nb}$ over $\mathrm{U}$ cover a wide range from 24 to 56 similar to MORB (Hofmann, 1997; Hofmann et al., 1986; Sun et al., 2008) and overlap with those from Faial and Pico (Fig. 7). Both, $\mathrm{Nb} / \mathrm{U}$ and $\mathrm{Ce} / \mathrm{Pb}$ are not clearly correlated with either $\mathrm{H}_{2} \mathrm{O}$ or $\mathrm{CO}_{2}$. The overlap of trace element ratios from the seemingly unaltered samples from the nearby islands and those from the southwestern Princessa Alice bank suggests that some of 
these trace element characteristics (e.g., $\mathrm{Nb} / \mathrm{Zr}$, REEs) may still be reliable tracers for melting and source signatures of the lavas. The ${ }^{87} \mathrm{Sr} /{ }^{86} \mathrm{Sr}$ isotope ratios are positively correlated with $\mathrm{MgO}$ and display a much less well-defined trend with $1 / \mathrm{Sr}$ ratios (Fig. 8). The ${ }^{87} \mathrm{Sr} /{ }^{86} \mathrm{Sr}$ isotope ratios are however, broadly positively correlated with $\mathrm{Nd} / \mathrm{Sr}$ (Fig. 8).

The geochemical variability with water depth shows that $\mathrm{CaO}$ generally decreases whereas calculated $\mathrm{H}_{2} \mathrm{O}$ contents, $\mathrm{Pb}$ concentrations, ${ }^{87} \mathrm{Sr} /{ }^{86} \mathrm{Sr}$ and $\delta^{18} \mathrm{O}_{\mathrm{V} \text {-SMOw }}$ broadly increase with shallower depth (Fig. 9). The $\mathrm{CaO}$ contents are lowest and $\mathrm{MgO}$ contents are highest in the topmost three samples, which are predominantly quartz-chlorite altered and reveal massive mass transfers facilitated by the extremely high water-rock ratios during alteration.

\section{DISCUSSION}

Here, we discuss the geophysical, petrological and geochemical features of the western Princessa Alice bank profile. We differentiate between primary, igneous signatures and those introduced by extensive alteration.

\section{INTERPRETATION OF SEISMIC IMAGERY}

In agreement with the ROV-imagery and samples, and two previous seismic studies from the Azores at the Terceira Rift (Weiß et al., 2015) and São Jorge Island (Marques et al., 2018) we interpret units P1-P8 as lava flows (Fig. 2). In agreement with geodynamic models of Cannat et al. (1999), Gente et al. (2003) and samples from Beier et al. (2015) these lava flows formed during the prolonged magmatic activity at Princessa Alice bank at $\sim 10-4$ Ma. The lateral intercalation of PS1 and P1 suggests emplacement synchronous to the opening of the rift basin. There is no evidence for a tectonic overprint implying that P2 to P8 were emplaced after the main phase of rifting occurred. ROV-samples were taken from units P2-P5. The relatively undisturbed vertical succession proves that the rock samples indeed preserve a sequence with increasing age from top to bottom (Fig. 9). Yet, the relative depth of the samples beneath the rift shoulder is larger than the depth of the related units P2-P5 beneath the plateau away from the rift. The sedimentary sequence observed in unit PS2 represents a younger unit that formed between P7 and P8 during the final phases of igneous activity. 


\section{Petrological AND GeOCHeMiCAL Signatures}

\section{IGNEOUS GEOCHEMICAL SIGNATURES}

The igneous geochemical signatures of mafic intraplate magmas will be influenced by shallow level processes such as fractional crystallization, the melting process and diversity of mantle source signatures (Hofmann, 2003). The broad spread in major element compositions (Fig. 5) and the correlation of $\mathrm{CaO}$ contents with $\mathrm{CO}_{2}$ suggests that these have also variably been influenced by alteration. We do observe a scatter in $\mathrm{SiO}_{2}, \mathrm{CaO}, \mathrm{K}_{2} \mathrm{O}$ and $\mathrm{Na}_{2} \mathrm{O}$ to both higher and lower contents compared to the islands but similar to submarine samples published from western and eastern Princessa Alice bank. The MgO contents broadly cover a similar range than most of the islands. The precursor mineral assemblage consisted of plagioclase and clinopyroxene suggesting that much of the range in $\mathrm{MgO}$ could be explained by fractional crystallization of clinopyroxene and plagioclase comparable to what has been observed on the islands (Beier et al., 2012; Larrea et al., 2018; Larrea et al., 2014). Titanium has generally been considered to be relatively immobile due to its High Field Strength Element (HFSE) nature. The significantly lower $\mathrm{TiO}_{2}$ contents of the western Princessa Alice bank lavas and the correlation with ratios of the Light Rare Earth Elements/Heavy Rare Earth Elements (LREE/HREE) and the HREE, e.g., $(\mathrm{Ce} / \mathrm{Yb})_{\mathrm{N}}, \mathrm{La} / \mathrm{Yb}, \mathrm{Ti} / \mathrm{Yb}$ and $\mathrm{Tb} / \mathrm{Yb}$ suggests that the lower $\mathrm{TiO}_{2}$ contents are derived either from a more depleted mantle source or distinctively higher degrees of partial melting (Fig. 7).

In the Azores, the enriched and depleted mantle source endmembers cover the range observed globally (Hofmann, 2003). In addition a uniquely enriched mantle source influences the trace element and isotope compositions underneath eastern São Miguel (Béguelin et al., 2017; Beier et al., 2018b; Beier et al., 2007; Elliott et al., 2007). The lower $\mathrm{TiO}_{2}$ contents of the Princessa Alice bank lavas could be explained by a less enriched mantle source composition (Fig. 7) but the $\mathrm{Nb} / \mathrm{U}$ ratios overlap much of the variability of the Azores islands. Ratios of the HFSE $(\mathrm{Nb} / \mathrm{Zr}, \mathrm{Ta} / \mathrm{Hf})$ extend to both lower and higher ratios than those published from Princessa Alice bank and Pico and Faial while some ratios are as low as those observed at Condor rift. The overall variability of these ratios at western Princessa Alice bank is slightly larger than that observed at Santa Maria and Corvo and Flores (Beier et al., 2013; Genske et al., 2016) but generally extends to lower values. The similarity of some samples to those from Condor rift with relatively low $\mathrm{Nb} / \mathrm{Zr}$ could imply systematic changes in degree of partial melting or source composition through the profile (Romer et al., 2018); we note, however that samples with low and high $\mathrm{Nb} / \mathrm{Zr}$ occur throughout the profile both at deeper 
and shallower levels. The large range in $\mathrm{Nb} / \mathrm{Zr}$ is negatively correlated with $\mathrm{Tb} / \mathrm{Yb}$ ratios of the western Princessa Alice bank lavas and could result from volumetric changes in epidote (Anenburg et al., 2015; Frei et al., 2004). The chondrite-normalized REE patterns of the epidote crystals in our samples are flat, suggesting that the impact from epidote may be small (supplemental Fig. A1). In contrast, values of $\mathrm{Nb} / \mathrm{Ta}$ deviate from commonly observed OIB and MORB compositions (Pfänder et al., 2007) with higher Nb/Ta values of 17 to 19 . These values are also slightly higher but less variable than those observed in lavas from the Azores islands ( $\mathrm{Nb} / \mathrm{Ta}$ typically ranging from 14 to 18$)$. However, the $\mathrm{Zr} / \mathrm{Hf}$ ratios largely overlap with compositions from the Azores islands. The fractionation of $\mathrm{Nb}$ from $\mathrm{Ta}$ is evident in the profile with highest and more uniform $\mathrm{Nb} / \mathrm{Ta}$ observed in the deeper section, whereas $\mathrm{Nb} / \mathrm{Ta}$ variability increases towards the top of the profile, where low ratios correlate with lower $\mathrm{CaO}$ and higher $\mathrm{MgO}$ contents, suggesting that the HFSE systematics may be disturbed by alteration. The latter will be discussed further below, but we conclude that the heterogeneity in HFSE ratios is partially overridden by hydrothermal alteration (chloritization) and does not reflect initial heterogeneity of the mantle source.

Lower LREE/HREE ratios and lower $\mathrm{TiO}_{2}$ contents in the Princessa Alice bank lavas can potentially be explained by the incorporation of deep-sea mud, which has elevated HREE concentrations (200-430 ppm total HREE) and low $\mathrm{TiO}_{2}$ contents mainly as a result of the formation hydrothermal iron-oxyhydroxides and phillipsite (Kato et al., 2011). The lower LREE/HREE ratios at Princessa Alice bank generally result from lower concentrations of the LREE but comparable or even lower HREE contents compared to the non-altered submarine and subaerial lavas (Fig. 6 and 7 (with the exception of sample IEAZO1164)). In addition, relatively constant $\mathrm{Ce} / \mathrm{Ce}^{*}$ and smooth $\mathrm{REE}$ pattern (Fig. 6) rule out a significant impact by ferromanganese crusts or phosphorization (Tejada et al., 2016) unlike observed in the Louisville seamounts (Beier et al., 2011). In addition, Ti/Sm (Fig. 7), Ti/Gd and Ti/Zr ratios (not shown) overlap with those from the islands suggesting that $\mathrm{TiO}_{2}$ contents have not been influenced by alteration. Thus, the REE and Ti contents in the Princessa Alice bank lavas can be used to decipher the source and melting conditions in contrast to $\mathrm{Nb}$, Ta and $\mathrm{Hf}$ which may partially be mobilized and fractionated during alteration.

The relatively lower trace element abundances and lower $\mathrm{TiO}_{2}$ contents and lower LREE/HREE and HREE ratios of the Princessa Alice bank lavas (Fig. 7) thus likely result from increasing degrees of partial melting during the initial emplacement of the lavas from the melting anomaly at $10 \mathrm{Ma}$ (Beier et al., 2015; Cannat et al., 1999; Gente et al., 2003) and are similar to those observed in enriched mid-ocean ridge basalts (E-MORB) that may form 
from more enriched sources and lower degrees of partial melting compared to normal MORB (Donnelly et al., 2004; Haase et al., 2011). The absence of a strong residual garnet signature in the western Princessa Alice bank lavas and higher degrees of partial melting exceeding 10 $\%$ (Fig. 7) compared to much lower degrees of melting of $<5 \%$ on the islands and most samples from the eastern Princessa Alice bank and Condor rift indicates a change in the melting regime. We note that younger samples from Condor rift display similarly low degrees of partial melting at higher residual garnet contents (Fig. 7). The much younger nature of the Condor rift relative to the Princessa Alice bank (Romer et al., 2018) suggests that the average depth of melting increases with time.

We conclude that despite the extreme degrees of alteration, the less enriched nature of the western Princessa Alice bank samples evident from the REE systematics results from the arrival of a melting anomaly underneath the lithosphere causing higher degrees of melting of a variably enriched mantle source, similar to what is being erupted nowadays on the islands (Beier et al., 2018b). The extremely altered nature of the samples however, suggests that posteruptive modification had a significant impact on the composition of the samples including some of the HFSE, which we will discuss in more detail below.

\section{Alteration Signatures}

The first-order observation on the western Princessa Alice bank profile is that the precursor rock assemblage has been replaced almost entirely by metamorphic mineral assemblages that grade from greenschist to subgreenschist facies (Fig. 3 and 4). Primary clinopyroxene is always replaced by chlorite except in sample IEAZO1120. Anorthite-rich plagioclase has almost exclusively been replaced by albite leading to a release of $\mathrm{Ca}$ and $\mathrm{Al}$ from the igneous assemblage into the surrounding ocean water (supplemental Table A1). At shallower water depth the secondary albites have commonly been replaced by quartz, chlorite and illite (Fig. 3 and 4) in rocks that show evidence for strong chemical exchange with circulating seawater. The occurrence of epidote (Fig. 4), actinolite, and titanite in the lowermost indicates true greenschist facies conditions under lower water-to-rock ratios. Least squares modelling of the mineral assemblage were performed based on the average mineral major element geochemistry for chlorite, epidote, plagioclase, clinopyroxene, actinolite, titanite and illite and idealized compositions for quartz, calcite and hematite. Boundary conditions (actinolite max $5 \%$ and $0 \%$ for samples $<1,754 \mathrm{mbsl}$; chlorite $>5 \%$; formation of clinopyroxene suppressed except for IEAZO1120 and IEAZO1156; formation of plagioclase suppressed for sample 
IEAZO1122) were based on the petrological observations. Figure 3 shows that the calculated and analyzed geochemical compositions largely overlap (Fig. 3) indicating that much of the major element variability may indeed reflect variations in the alteration assemblage. A correlation of $\mathrm{MgO}$ and $\mathrm{H}_{2} \mathrm{O}$ (Fig. 5) implies that much of the $\mathrm{H}_{2} \mathrm{O}$-rich nature of the samples must be controlled by the occurrence of $\mathrm{Mg}$-rich chlorite that formed from the igneous clinopyroxene and plagioclase.

To date, few stratigraphic profiles are available through altered oceanic crust and are restricted to Deep See Drilling Project (DSDP) Hole 504B and Ocean Drilling Program (ODP) Hole 1256D both of which are situated on Pacific normal oceanic crust. Pervasive rock alteration is overall minor except in halos along veins and in the dike-lava transition zone (Alt et al., 1986; Alt et al., 1996; Fisher et al., 2014). This poses the question as to which geodynamic process results in the extreme extents of alteration observed at the western Princessa Alice bank profile. In both Pacific drill-sites changes in degree of alteration are correlated with the rock lithology (higher at flow contacts and in brecciated units) and drill depth (alteration peeks in the dike-lava transition zone). As opposed to the Princessa Alice bank profile, fresh igneous rock assemblages are generally preserved in the Pacific drill-sites (Fisher et al., 2014).

At the western Princessa Alice bank, the massive and distinct occurrence of epidote in veins and alteration patches in the host rock is striking in the lower part of the profile. The preferred formation of epidote could result from the focusing of hydrothermal fluids at the transition between the reaction zone and up-flow zone similar to what was proposed by replacive epidote in the sheeted dikes of the Troodos ophiolite in Cyprus (Gillis, 2002; Richardson et al., 1987). If the western Princessa Alice bank profile represented a hydrothermal up-flow zone this could explain the pervasive alteration compared to $504 \mathrm{~B}$ or $1256 \mathrm{D}$ as well as the formation of massive epidote veins. But the lack of intensive silicification and sulfidization in the shallower section is inconsistent with a hydrothermal upflow zone. Instead only the basaltic samples of the lower part of the profile (to 1,750 mbsl water depth), are altered to true greenschist-facies assemblages with abundant epidote. The alteration of the shallower part of the profile to chlorite/smectite-quartz-anatase however took place under lower metamorphic grades (Fig. 3). This change in mineral composition occurs between 1,900 and 1,750 mbsl (Fig. 3). Actinolite commonly occurs in small patches (Fig. 4) rather than in larger aggregates, suggesting that the entire system may have reached full greenschist-facies conditions for a relatively short period of time. A change from calcite and quartz veins to epidote and chlorite veins and vice versa is common, i.e. in sample IEAZO1120 calcite replaces chlorite forming 
from clinopyroxene, whereas in sample IEAZO1122 we observe replacement of a calcite vein with epidote inclusions by chlorite (Fig. 4f). We interpret these features to represent the cooling of the hydrothermal system along with increased fluid flow. Due to the decreasing temperatures, quartz forms as a late-stage mineral, filling voids and cracks. We do, however, find evidence that in some cases quartz is surrounded by interstitial epidote (Fig. 4) suggesting that the system developed through several phases of hydrothermal activity. These transients may indicate that the system had a distinct magmatic and hydrothermal pulse during each eruptive period (Fig. 2).

The timing of these events is difficult to link to specific eruptive events. We used the ${ }^{87} \mathrm{Sr} /{ }^{86} \mathrm{Sr}$ ratios of planktic foraminifera from indurated calcareous ooze covering some of the lava samples to retrieve minimum ages for the exposure of the rock from matching the measured values to the time at which seawater had that specific ${ }^{87} \mathrm{Sr} /{ }^{86} \mathrm{Sr}$ isotope composition (Farrell et al., 1995). Based on ${ }^{87} \mathrm{Sr} /{ }^{86} \mathrm{Sr}$ values as low as 0.708892 , these "exposure ages" are as high as $6.5 \mathrm{Ma}$, which is consistent with geophysical and geochemical estimates of igneous activity in the Princessa Alice bank region (Beier et al., 2015; Cannat et al., 1999; Gente et al., 2003). The apparent decrease in exposure age down section (Fig. 9a) may relate to more recent down-faulting of the graben floor during which the lower slopes of the headwall were exposed.

\section{Water-rock ratios ANd Conditions of alteration at Princessa Alice} BANK

The extensive degree of alteration at the western Princessa Alice bank compared to 504B and $1256 \mathrm{D}$ and the stratigraphic sampling allows characterizing the evolution of the hydrothermal system with time. The systematic change of the $\mathrm{CaO}, \mathrm{H}_{2} \mathrm{O}$, and $\mathrm{Pb}$ contents and ${ }^{87} \mathrm{Sr} /{ }^{86} \mathrm{Sr}$ and $\delta^{18} \mathrm{O}_{\mathrm{V} \text {-SMOw }}$ isotope ratios with depth (Fig. 9) suggests gradual changes in the degree of alteration throughout the profile. The seismic imagery does not show any evidence for large tectonic disturbances suggesting that the geochemical changes occur vertically within the profile and that an extensive horizontal elemental transport did not take place. Bach et al. (2013) suggested that changes in major element concentration significantly higher than $10 \%$ relative may be considered signs of significant metasomatic mass transfer. Changes with this magnitude occur rarely and are commonly coupled to either relatively high temperatures or a relatively high fluid flux. The changes in $\mathrm{CaO}$ and $\mathrm{MgO}$ contents (Fig. 5 and 9) exceed $10 \%$ significantly and a depletion of $\mathrm{CaO}$ is correlated with a broad relative enrichment of $\mathrm{MgO}$ 
towards shallower depths. These changes of the major element compositions are accompanied by changes in trace element compositions (Fig. 9). Lead concentrations increase with decreasing depth suggesting an addition of $\mathrm{Pb}$ from seawater incorporated mainly into chlorites. Strontium concentrations increase during the first $300 \mathrm{~m}$ of the profile (Fig. 9) prior to decreasing to almost zero to the upper part of the profile. Decreasing Sr contents could be explained by changes in plagioclase, the main phase of $\mathrm{Sr}$ in mafic igneous rocks, however, we do not observe systematic changes in plagioclase breakdown through the profile. Figure $8 \mathrm{~b}$ also implies that 2-component mixing with seawater cannot simply explain the Princessa Alice bank compositions. Thus, we conclude that much of the change in $\mathrm{Sr}$ contents may best be explained by incorporation into epidote in the lower profile sections and albite in the topmost part of the profile (Figs. 3, 8 and 9). Assuming a primary Sr content of $165 \mathrm{ppm}$ inferred from the highest values in sample IEAZO1120, a leaching of up to $96 \%$ of $\mathrm{Sr}$ is required suggesting a large amount of fluid circulating or a long period of hydrothermal circulation.

Calculating the water-rock ratios using the ${ }^{87} \mathrm{Sr} /{ }^{86} \mathrm{Sr}$ isotope compositions shows that the ratios increase logarithmically to the top of the profile exceeding those observed at 504B and 1256D. The crust-seawater exchange indicated by the ${ }^{87} \mathrm{Sr} /{ }^{86} \mathrm{Sr}$ isotope profile of crustal rocks at Princessa Alice bank (Fig. 9) appears to be much greater than what drill core and fracture zone sampling of oceanic crust in the Pacific have indicated (Teagle et al., 2003) (Fig. 9e). In these crustal profiles, the upper crust is highly non-uniform in ${ }^{87} \mathrm{Sr} /{ }^{86} \mathrm{Sr}$ but the majority of lavas appear largely unaffected by reactions with seawater. This has been interpreted along the lines of kinetically limited exchange of $\mathrm{Sr}$ between rocks and fluids at low temperatures. Instead, $\mathrm{Sr}$ isotopic compositions of crustal rocks are more uniformly elevated in the sheeted dike complex where higher temperatures, and hence more rapid $\mathrm{Sr}$ exchange prevailed (Teagle et al., 2003). Isotopic compositions of the dike rocks were used by these authors to compute time-integrated fluid fluxes between 1.5 and $3.2 \times 10^{6} \mathrm{~kg} / \mathrm{m}^{2}$ using a one-dimensional model of fluid recharge and kinetic limited exchange between rocks and fluid (Harris et al., 2017). Barker et al. (2008) showed that the fluxes calculated from simple mass balance for $\mathrm{Sr}$ are on the same order of magnitude. Employing the more sophisticated model of recharge and exchange is difficult for the Princessa Alice bank profile, because we do not know where the transition between the lava pile and the sheeted dyke complex is. If we assume that the rocks with the lowest water-rock ratios in water depths $>$ 2,200 mbsl represent the sheeted dike complex, we can compare the average water-rock ratio $(2.03 \pm 0.91, n=7)$ with water-rock ratios for the sheeted dyke complex from the Pito Fracture 
Zone, Hess Deep, and Hole 504B, which are between 0.6 and 0.9. These higher water-rock ratios for the sheeted dyke complex at Princessa Alice bank is consistent with the overall pervasive style of alteration that has affected all rocks from the Princessa Alice bank profile.

The extremely high water-rock ratios for the topmost part of the Princessa Alice bank crustal section are consistent with changes in $\mathrm{CaO}$ contents at shallower levels where phases that incorporate significant amounts of $\mathrm{CaO}$ (e.g., epidote, calcite) are not developed. In addition, we did not observe any evidence for the presence of other, secondary $\mathrm{CaO}$-mineral phases (e.g., anhydrite, laumontite, prehnite). The extensive formation of chlorite at shallower profile levels increases the total amount of $\mathrm{MgO}$ extracted from the circulating seawater. The relatively high water-rock ratios required for the observed mineral assemblage cannot be explained by assuming that the western Princessa Alice bank profile represents a typical crustal section such as has been sampled before by ocean drilling (Holes 504B and 1256D) in the eastern equatorial Pacific (Harris et al., 2017; Teagle et al., 2003) or at Pito Fracture Zone (Barker et al., 2008). The intensity of alteration is much greater at Princessa Alice bank. The section is also dissimilar to hydrothermal up-flow zone, such as the ones in the Troodos ophiolite (Gillis, 2002; Richardson et al., 1987). This is because the high ${ }^{87} \mathrm{Sr} /{ }^{86} \mathrm{Sr}$ ratios in concert with the enrichment in $\mathrm{MgO}$ indicates that fairly unreacted seawater - and not upflowing hydrothermal fluid - was involved in rock alteration. Also, the shallower parts of hydrothermal up-flow zones are commonly silicified and sulfidized, which is not the case at Princessa Alice Bank.

One crucial physical parameter which influences much of the alteration assemblage is the temperature at which hydrothermal alteration occurs. Here, we use $\delta^{18} \mathrm{O}_{\mathrm{V}-\mathrm{SMOW}}$ ratios from quartz, epidote and calcite mineral separates (Fig. 9) assuming an initial isotopic composition of the fluid of $\delta^{18} \mathrm{O}_{\mathrm{V} \text {-SMOW }}=0,1$, and $2 \%$ (Table 2). The higher values for $\delta^{18} \mathrm{O}_{\mathrm{V} \text {-SMOw }}$ of the fluid are probably more representative for the lowermost samples with unradiogenic ${ }^{87} \mathrm{Sr} /{ }^{86} \mathrm{Sr}$ ratios. Due to the uncertainties in the initial fluid composition, a temperature profile cannot be established using the data presented. It is likely, however, that the $\delta^{18} \mathrm{O}$ values of the fluids were higher deeper in the crust, because greater depths commonly equate to longer fluid flow paths which, in turn, means more rock-dominated compositions (Gregory and Taylor Jr, 1981). Hence, deeper samples may represent higher temperatures (e.g., c. $300^{\circ} \mathrm{C}$ in the deepest sample, corresponding to a $\delta^{18} \mathrm{O}_{\text {fluid }}$ of $1 \%$ ) as compared to ca. $200^{\circ} \mathrm{C}$ in the topmost samples (for $\delta^{18} \mathrm{O}_{\text {fluid }}$ of $0 \%$ ). Higher temperatures at the base of the profile are also supported by the presence of albite, epidote and actinolite; i.e. true greenschist-facies conditions. The quartz-chlorite samples from the shallower profile section are consistent with lower 
temperatures and with the idea that recharge of seawater affected the rocks in the top of the profile.

We conclude that the Princessa Alice bank profile displays increasing water-rock ratios from bottom to top of the profile accompanied by decreasing alteration signatures. A single exposure age at the top of the profile may suggest that the topmost units have been exposed to the alteration process longer and that the extent of water-rock ratios and degree of alteration may ultimately be controlled by the duration of hydrothermal activity rather than temperatures.

\section{GEODYNAMIC EVOLUTION}

The formation and evolution of the anomalous bathymetric anomaly (Fig. 1) remains a matter of active debate (Miranda et al., 2018; O’Neill and Sigloch, 2018; Vogt and Jung, 2018) but there is common agreement that much of the volcanism causing the Azores submarine plateau is caused by a combination of an upper mantle melting anomaly (O'Neill and Sigloch, 2018; Yang et al., 2006) and the regional tectonic setting (Vogt and Jung, 2018).

The formation of the substantial volume of the Plateau during the initial arrival of the melting anomaly underneath the lithosphere will result in larger degrees of partial melting (Beier et al., 2015) and a lesser extent of trace element and potentially also isotopic enrichment of the lavas (McKenzie and Bickle, 1988; Rubin and Sinton, 2007; Rubin et al., 2009; Stracke and Bourdon, 2009). Lavas from Princessa Alice bank are situated at lithospheric ages of $10 \mathrm{Ma}$ suggesting that the lavas formed at or close to the mid-Atlantic Ridge (Gente et al., 2003). The tectonic half-graben at which the western Princessa Alice bank profile formed may be situated along a previous transform fault system of the midAtlantic Ridge at 10 Ma. The occurrence of significantly higher degrees of partial melting indicates that the western Princessa Alice bank profile formed indeed during the initial phase of volcanism in the Azores based on their relatively elevated ${ }^{206} \mathrm{~Pb} /{ }^{204} \mathrm{~Pb}, \mathrm{Nb} / \mathrm{Zr}$ and $\mathrm{Ba} / \mathrm{La}$ compared to normal MORB (Beier et al., 2015). The extensive graben structure at which the profile is situated suggests that much of the rifting activity must have occurred during emplacement of the igneous units similar to what is currently observed along the Terceira Rift axis (Beier et al., 2008; Vogt and Jung, 2018). Thus, we interpret the profile to represent the initial stages of the formation of the Azores Plateau, however, we note that we did not find any clear evidence for the occurrence of a voluminous tholeiitic lava stage in the profile as opposed to other large igneous provinces which may result from the much smaller buoyancy 
flux and smaller size of the Azores melting anomaly (Davies, 1988; O'Neill and Sigloch, 2018; Sleep, 1992). Tholeiitic lavas have commonly been defined based on their low alkalinity, however, fluid flow has likely compromised the $\mathrm{Na}_{2} \mathrm{O}$ and $\mathrm{K}_{2} \mathrm{O}$ contents of the Princessa Alice bank profile lavas (Fig. 5) making a clear distinction between tholeiitic and alkaline lavas difficult. Published geochemical data from Princessa Alice bank imply that some of the lavas may indeed be tholeiitic to transitional alkalic in composition, however, the relatively radiogenic $\mathrm{Pb}$ isotope ratios and relatively enriched trace element signatures indicate the involvement of an enriched source during melting (Beier et al., 2015).

Geochemical evidence for extensive assimilation of highly altered oceanic crust has been suggested for the Ontong Java Plateau based on elevated $\mathrm{Cl} / \mathrm{K}$ ratios of the basaltic lava that built up the plateau (Michael, 1999). But, unlike $\mathrm{Cl}, \mathrm{H}_{2} \mathrm{O}$ was apparently not transferred to the magma in the course of assimilation at the Ontong Java Plateau (Michael, 1999), which would indicate that the type of hydrothermal altered crust we encountered at the Princessa Alice bank may not be the type of assimilated crust required to explain the geochemical composition of the Ontong Java Plateau basalts. The intense magmatic activity occurring over several million years along with the strong tectonic regime in the Azores (Fernandes et al., 2018; Fontiella et al., 2018; Vogt and Jung, 2018) apparently opens pathways for the circulation of hydrothermal fluids over relatively long timescales, contrasting the relatively short-lived systems along mid-ocean ridges. The degree of alteration may only be limited to an area of several meters around the fault plane providing pathways for the fluid (Kodera et al., 2005). Commonly these fault planes have been considered one controlling factor in the formation of active hydrothermal vent fields (German and Parson, 1998). In the Azores the tectonic activity occurs across the entire submarine plateau and the islands (Fernandes et al., 2006; Fernandes et al., 2018; Krause and Watkins, 1970; Luis et al., 1998; Luis et al., 1994; Marques et al., 2013). Thus, the high degrees of alteration of the submarine igneous Azores plateau may be widespread. The altered nature of the lower submarine oceanic crust in these environments will change the interpretation of geochemical signatures erupted both submarine and subaerially because the ubiquitous occurrence of assimilation during magma ascent is commonly based on source signatures that will be related to relatively fresh igneous signatures (Genske et al., 2013; Larrea et al., 2013; Larrea et al., 2018; Larrea et al., 2014). If these processes also operate in other large igneous provinces the exchange of $\mathrm{Na}$ and $\mathrm{Mg}$ and many of the hydrothermally mobile trace elements between the crust and ocean may be significant on the timescales of formation of these edifices. The extensive, long-lived emplacement of these hydrothermal systems, the degree of alteration and the large volumes of 
lavas erupting in large igneous provinces globally could add to the significant climate and environmental impact of large igneous provinces (Courtillot and Renne, 2003).

\section{CONCLUSiOnS}

Based on the petrological, geochemical and geodynamic observations we conclude that

(1) Lavas from a 1,045 m high submarine stratigraphic profile along a fault system at the southwestern Princessa Alice bank of the Azores submarine Plateau formed by slightly higher degrees of partial melting of an enriched mantle source at $\sim 10 \mathrm{Ma}-6 \mathrm{Ma}$ as a result of the arrival of a melting anomaly underneath the mid-Atlantic Ridge.

(2) The state of alteration of these lavas and the exposure ages of the lavas suggests that continuous hydrothermal circulation changed the composition of the lavas. The oldest exposure ages of up to $6 \mathrm{Ma}$ occur in the top of the profile where the highest water to rock ratios were observed. This implies that the duration of alteration instead of the overall degree of alteration may control the final composition.

(3) The extensive degree of alteration at Princessa Alice bank results from a combination of extensive, long-lived magmatic activity from the melting anomaly and the formation of fault systems during rift basin opening providing pathways for hydrothermal fluids.

(4) The elemental fluxes to and from these igneous units and the overall duration and extent of alteration observed in the Azores may change the interpretation of the representativeness of samples from oceanic large igneous provinces. If samples of oceanic plateaus are pervasively altered, the flux of large amounts of $\mathrm{Na}_{2} \mathrm{O}, \mathrm{CaO}$ and $\mathrm{Sr}$ and the isotopic exchange between the ocean and igneous crust may significantly alter the ocean chemistry in the immediate vicinity of large igneous provinces.

(5) The impact of alteration during the formation of large igneous provinces may have been underestimated and the longevity of these systems may significantly contribute to the element exchange between the ocean and crust.

\section{ACKNOWLEDGMENTS}

We thank captain J. F. Schubert and M. Schneider and their crews for their help in carrying out two successful cruises on R/V Meteor during M128 and M113. We particularly acknowledge the help and support of the captain and crew of M128 also during the ROV and TV grab operations. We acknowledge the help and support of V. Ratmeyer and his ROV team 
during the operations. The authors acknowledge help by K. Knevels in the processing of the seismic imagery. We acknowledge help by M. Kucera in determining the exposition age of the carbonate vein. We thank M. Jackson and two anonymous reviewers for their constructive comments that have helped improving the manuscript and thank W. Sun for editorial handling. The cruise was financed by the German Research Foundation (DFG) and the Senatskomission für Ozeanographie. C. Beier and W. Bach thank H.P. Einar and B.D. König for their support and encouragement during the sometimes difficult and changing weather and technical conditions during both cruises and during SO263 when this manuscript was drafted.

\section{REFERENCES:}

Albarède, F., Michard, A., Minster, J.F., Michard, G., $1981 .{ }^{87} \mathrm{Sr} /{ }^{86} \mathrm{Sr}$ ratios in hydrothermal waters and deposits from the East Pacific Rise at $21^{\circ} \mathrm{N}$. Earth and Planetary Science Letters 55, 229-236. doi:10.1016/0012-821X(81)90102-3

Alt, J.C., Honnorez, J., Laverne, C., Emmermann, R., 1986. Hydrothermal alteration of a 1 $\mathrm{km}$ section through the upper oceanic crust, Deep Sea Drilling Project Hole 504B: Mineralogy, chemistry and evolution of seawater-basalt interactions. Journal of Geophysical Research: Solid Earth 91, 10309-10335. doi:10.1029/JB091iB10p10309

Alt, J.C., Laverne, C., Vanko, D.A., Tartarotti, P., Teagle, D.A.H., Bach, W., Zuleger, E., Erzinger, J., Honnorez, J., Pezard, P.A., Becker, K., Salisbury, M.H., Wilkens, R.H., 1996. Hydrothermal alteration of a section of upper oceanic crust in the eastern Equatorial Pacific; a synthesis of results from Site 504 (DSDP legs 69-70, and 83, and ODP legs 111, 137, 140, and 148). Proceedings of the Ocean Drilling Program, Scientific Results 148, 417.

Alt, J.C., 1997. Hydrothermal Alteration and Mineralization of Oceanic Crust: Mineralogy, Geochemistry, and Processes, Volcanic Associated Massive Sulfide Deposits: Processes and Examples in Modern and Ancient Settings. Society of Economic Geologists.

Alt, J.C., Teagle, D.A., 2000. Hydrothermal alteration and fluid fluxes in ophiolites and oceanic crust. Geological Society of America, Special paper 349, 273-282.

Anenburg, M., Katzir, Y., Rhede, D., Jöns, N., Bach, W., 2015. Rare earth element evolution and migration in plagiogranites: a record preserved in epidote and allanite of the Troodos ophiolite. Contributions to Mineralogy and Petrology 169, 1-19. doi:10.1007/s00410-0151114-y 
Asimow, P.D., Dixon, J.E., Langmuir, C.H., 2004. A hydrous melting and fractionation model for mid-ocean ridge basalts: Application to the Mid-Atlantic Ridge near the Azores. Geochemistry, Geophysics, Geosystems 5, Q01E16. doi:10.1029/2003GC000568

Bach, W., Peucker-Ehrenbrink, B., Hart, S.R., Blusztajn, J.S., 2003. Geochemistry of hydrothermally altered oceanic crust: DSDP/ODP Hole 504B - implications for seawatercrust exchange budgets and $\mathrm{Sr}-$ and $\mathrm{Pb}$-isotopic evolution of the mantle. Geochemistry, Geophysics, Geosystems 4, 8904. doi:10.1029/2002GC000419

Bach, W., Jöns, N., Klein, F., 2013. Metasomatism Within the Ocean Crust, in: Harlov, D.E., Austrheim, H. (Eds.), Metasomatism and the Chemical Transformation of Rock: The Role of Fluids in Terrestrial and Extraterrestrial Processes. Springer Berlin Heidelberg, Berlin, Heidelberg, pp. 253-288.

Barker, A.K., Coogan, L.A., Gillis, K.M., Weis, D., 2008. Strontium isotope constraints on fluid flow in the sheeted dike complex of fast spreading crust: Pervasive fluid flow at Pito Deep. Geochemistry Geophysics Geosystems 9. doi:10.1029/2007gc001901

Bastos, L., Osório, J., Hein, G., Landau, H., 1996. GPS derived displacements in the Azores triple junction region., in: Beutler, G., Hein, G.W., Melbourne, W.G., Seeber, G. (Eds.), GPS trends in Precise terrestrial, airborne and spaceborne applications. Springer, Berlin, pp. 99104.

Bayliss, P., 1975. Nomenclature of the trioctahedral chlorites. The Canadian Mineralogist 13, 178-180.

Béguelin, P., Bizimis, M., Beier, C., Turner, S., 2017. Rift-plume interaction reveals multiple generations of recycled oceanic crust in Azores lavas. Geochimica et Cosmochimica Acta 218, 132-152. doi:10.1016/j.gca.2017.09.015

Beier, C., Haase, K.M., Hansteen, T.H., 2006. Magma evolution of the Sete Cidades volcano, São Miguel, Azores. Journal of Petrology 47, 1375-1411. doi:10.1093/petrology/eg1014

Beier, C., Stracke, A., Haase, K.M., 2007. The peculiar geochemical signatures of São Miguel lavas: metasomatised or recycled mantle sources? Earth and Planetary Science Letters 259, 186-199. doi:10.1016/j.epsl.2007.04.038

Beier, C., Haase, K.M., Abouchami, W., Krienitz, M.-S., Hauff, F., 2008. Magma genesis by rifting of oceanic lithosphere above anomalous mantle: Terceira Rift, Azores. Geochemistry, Geophysics, Geosystems 9, Q12013. doi:10.1029/2008GC002112 
Beier, C., Vanderkluysen, L., Regelous, M., Mahoney, J.J., Garbe-Schönberg, D., 2011. Lithospheric control on geochemical composition along the Louisville Seamount Chain. Geochemistry, Geophysics, Geosystems 12, Q0AM01. doi:10.1029/2011gc003690

Beier, C., Haase, K.M., Turner, S.P., 2012. Conditions of melting beneath the Azores. Lithos 144-145, 1-11. doi:10.1016/j.lithos.2012.02.019

Beier, C., Mata, J., Stöckhert, F., Mattielli, N., Brandl, P.A., Madureira, P., Genske, F.S., Martins, S., Madeira, J., Haase, K.M., 2013. Geochemical evidence for melting of carbonated peridotite on Santa Maria Island, Azores. Contributions to Mineralogy and Petrology 165, 823-841. doi:10.1007/s00410-012-0837-2

Beier, C., Haase, K.M., Abouchami, W., 2015. Geochemical and geochronological constraints on the evolution of the Azores Plateau, in: Neal, C.R., Sager, W.W., Sano, T., Erba, E. (Eds.), Geological Society of America Special Papers, The Geological Society of America, pp. 2788 .

Beier, C., Bach, W., Blum, M., Cerqueira, T., Ferreira, P.J., Genske, F.S., Haase, K.M., Kausche, A.H., Kemner, F., Klügel, A., Krumm, S.H., Kueppers, U., Leymann, T., Mai, A., Petry, F., Ratmeyer, V., Raeke, A., Rentsch, H., Romer, R.H.W., Sampaio, Í., Schade, T., Schleifer, B., Schröder, M.K., Skambraks, T.O., Storch, B., Vittori, V.F., Wefer, G., 2018a. Azores Plateau - Cruise No. M128 - July 02, 2016 - July 27, 2016 - Ponta Delgada (Portugal) - Ponta Delgada (Portugal). , METEOR-Berichte. DFG-Senatskommission für Ozeanographie, p. 41.

Beier, C., Haase, K.M., Brandl, P.A., 2018b. Melting and Mantle Sources in the Azores, in: Küppers, U., Beier, C. (Eds.), Volcanoes of the Azores. Springer Nature, Heidelberg.

Bond, D.P.G., Wignall, P.B., 2014. Large igneous provinces and mass extinctions: An update. Geological Society of America Special Papers 505, 29-55.

Bryan, S.E., Ernst, R.E., 2008. Revised definition of Large Igneous Provinces (LIPs). EarthScience Reviews 86, 175-202.

Burke, W.H., Denison, R.E., Hetherington, E.A., Koepnick, R.B., Nelson, H.F., Otto, J.B., 1982. Variation of seawater ${ }^{87} \mathrm{Sr} /{ }^{86} \mathrm{Sr}$ throughout Phanerozoic time. Geology 10, 516-519. 
Cannat, M., Briais, A., Deplus, C., Escartín, J., Georgen, J., Lin, J., Mercouriev, S., Meyzen, C., Muller, M., Pouliquen, G., Rabain, A., Silva, P.d., 1999. Mid-Atlantic Ridge - Azores hotspot interactions: along-axis migration of a hotspot-derived event of enhanced magmatism 10 to 4 Ma ago. Earth and Planetary Science Letters 173, 257-269.

Coffin, M.F., Eldholm, O., 1992. Volcanism and continental break-up: a global compilation of large igneous provinces, in: Storey, B.C., Alabaster, T., Pankhurst, R.J. (Eds.), Magmatism and the Causes of Continental Breakup. Geological Society of London, London, pp. 17-30.

Coffin, M.F., Eldholm, O., 1994. Large igneous provinces; crustal structure, dimensions, and external consequences. Reviews of Geophysics 32, 1-36.

Courtillot, V.E., Renne, P.R., 2003. On the ages of flood basalt events, The Earth's dynamics. Elsevier, Paris, France, pp. 113-140.

Davies, G.F., 1988. Ocean bathymetry and mantle convection; 1. Large-scale flow and hotspots. Journal of Geophysical Research B93, 10467-10480.

De Caritat, P., Hutcheon, I., Walshe, J.L., 1993. Chlorite Geothermometry - a Review. Clays and Clay Minerals 41, 219-239. doi:10.1346/Ccmn.1993.0410210

Donnelly, K.E., Goldstein, S.L., Langmuir, C.H., Spiegelman, M., 2004. Origin of enriched ocean ridge basalts and implications for mantle dynamics. Earth and Planetary Science Letters 226, 347-366.

Elderfield, H., Schultz, A., 1996. Mid-ocean ridge hydrothermal fluxes and the chemical composition of the ocean. Annual Review of Earth and Planetary Sciences 24, 191-224.

Elliott, T., Blichert-Toft, J., Heumann, A., Koetsier, G., Forjaz, V., 2007. The origin of enriched mantle beneath Sao Miguel, Azores. Geochimica et Cosmochimica Acta 71, 219240. doi:10.1016/j.gca.2006.07.043

Erba, E., 1994. Nannofossils and superplumes: The Early Aptian "nannoconid crisis". Paleoceanography 9, 483-501. doi:10.1029/94PA00258

Escartín, J., Cannat, M., Pouliquen, G., Rabain, A., 2001. Crustal thickness of V-shaped ridges south of the Azores: Interaction of the Mid-Atlantic Ridge $\left(36^{\circ}-39^{\circ} \mathrm{N}\right)$ and the Azores hot spot. Journal of Geophysical Research 106, 21,719 - 721,735. 
Farrell, J.W., Clemens, S.C., Peter Gromet, L., 1995. Improved chronostratigraphic reference curve of late Neogene seawater ${ }^{87} \mathrm{Sr} /{ }^{86} \mathrm{Sr}$. Geology 23, 403-406. doi:10.1130/00917613(1995)023<0403:ICRCOL>2.3.CO;2

Fernandes, R.M.S., Bastos, L., Miranda, J.M., Lourenco, N., Ambrosius, B.A.C., Noomen, R., Simons, W., 2006. Defining the plate boundaries in the Azores region. Journal of Volcanology and Geothermal Research 156, 1-9. doi:10.1016/j.jvolgeores.2006.03.019

Fernandes, R.M.S., Catalão, J., Trota, A., 2018. The Contribution of Space-Geodetic Techniques to the Understanding of the Present-Day Geodynamics of the Azores Triple Junction, in: Küppers, U., Beier, C. (Eds.), Volcanoes of the Azores. Springer Nature, Heidelberg.

Fisher, A.T., Alt, J., Bach, W., 2014. Chapter 4.2.2 - Hydrogeologic Properties, Processes, and Alteration in the Igneous Ocean Crust, in: Stein, R., Blackman, D.K., Inagaki, F., Larsen, H.-C. (Eds.), Developments in Marine Geology. Elsevier, pp. 507-551.

Fitton, J.G., Godard, M., 2004. Origin and evolution of magmas on the Ontong Java Plateau, in: Fitton, J.G., Mahoney, J.J., Wallace, P.J., Saunders, A.D. (Eds.), Origin and evolution of the Ontong Java Plateau. Geological Society of London, Special Publications, London, pp. $151-178$.

Fontiella, J., Sousa Oliveira, C., Rosset, P., 2018. Characterisation of Seismicity of the Azores Archipelago: An Overview of Historical Events and a Detailed Analysis for the Period 20002012, in: Küppers, U., Beier, C. (Eds.), Volcanoes of the Azores. Springer Nature, Heidelberg.

Frei, D., Liebscher, A., Franz, G., Dulski, P., 2004. Trace Element Geochemistry of Epidote Minerals. Reviews in Mineralogy and Geochemistry 56.

Frey, F.A., Coffin, M.F., Wallace, P.J., Weis, D., Zhao, X., Wise, S.W., Wähnert, V., Teagle, D.A.H., Saccocia, P.J., Reusch, D.N., Pringle, M.S., Nicolaysen, K.E., Neal, C.R., Müller, R.D., Moore, C.L., Mahoney, J.J., Keszthelyi, L., Inokuchi, H., Duncan, R.A., Delius, H., Damuth, J.E., Damasceno, D., Coxall, H.K., Borre, M.K., Boehm, F., Barling, J., Arndt, N.T., Antretter, M., 2000. Origin and evolution of a submarine large igneous province: the Kerguelen Plateau and Broken Ridge, southern Indian Ocean. Earth and Planetary Science Letters 176, 73-89. doi:10.1016/S0012-821X(99)00315-5 
Genske, F.S., Beier, C., Haase, K.M., Turner, S.P., Krumm, S., Brandl, P.A., 2013. Oxygen isotopes in the Azores islands: Crustal assimilation recorded in olivine. Geology 41, 491. doi:10.1130/G33911.1

Genske, F.S., Beier, C., Stracke, A., Turner, S.P., Pearson, N.J., Hauff, F., Schaefer, B.F., Haase, K.M., 2016. Comparing the nature of the western and eastern Azores mantle. Geochimica et Cosmochimica Acta 172, 76-92. doi:10.1016/j.gca.2015.08.019

Gente, P., Dyment, J., Maia, M., Goslin, J., 2003. Interaction between the Mid-Atlantic Ridge and the Azores hotspot during the last 85 Myr: Emplacement and rifting of the hot spotderived plateaus. Geochemistry, Geophysics, Geosystems 4, Q8514. doi:10.1029/2003GC000527

German, C.R., Parson, L.M., 1998. Distributions of hydrothermal activity along the MidAtlantic Ridge: interplay of magmatic and tectonic controls. Earth and Planetary Science Letters 160, 327-341. doi:10.1016/S0012-821X(98)00093-4

Gillis, K.M., 2002. The Rootzone of an Ancient Hydrothermal System Exposed in the Troodos Ophiolite, Cyprus. The Journal of Geology 110, 57-74. doi:10.1086/324205

Goldstein, S.J., Jacobsen, S.B., 1987. The $\mathrm{Nd}$ and $\mathrm{Sr}$ isotopic systematics of river-water dissolved material: Implications for the sources of $\mathrm{Nd}$ and $\mathrm{Sr}$ in seawater. Chemical Geology: Isotope Geoscience section 66, 245-272. doi:10.1016/0168-9622(87)90045-5

Gregory, R.T., Taylor Jr, H.P., 1981. An oxygen isotope profile in a section of Cretaceous oceanic crust, Samail Ophiolite, Oman: Evidence for $\delta^{18} \mathrm{O}$ buffering of the oceans by deep $(>5 \mathrm{~km})$ seawater-hydrothermal circulation at mid-ocean ridges. Journal of Geophysical Research: Solid Earth 86, 2737-2755. doi:10.1029/JB086iB04p02737

Haase, K.M., Stroncik, N., Beier, C., Timm, C., Schneider von Deimling, J., Kaif, S., Lopes, C., 2002. Cruise Report POS 286 RV Poseidon. 1-13.

Haase, K.M., Beier, C., Fretzdorff, S., Leat, P.T., Livermore, R.A., Barry, T.L., Pearce, J.A., Hauff, F., 2011. Magmatic evolution of a dying spreading axis: Evidence for the interaction of tectonics and mantle heterogeneity from the fossil Phoenix Ridge, Drake Passage. Chemical Geology 280, 115-125. doi:10.1016/j.chemgeo.2010.11.002

Harris, M., Coggon, R.M., Smith-Duque, C.E., Cooper, M.J., Milton, J.A., Teagle, D.A.H., 2015. Channelling of hydrothermal fluids during the accretion and evolution of the upper 
oceanic crust: $\mathrm{Sr}$ isotope evidence from ODP Hole 1256D. Earth and Planetary Science Letters 416, 56-66. doi:10.1016/j.epsl.2015.01.042

Harris, M., Coggon, R.M., Wood, M., Smith-Duque, C.E., Henstock, T.J., Teagle, D.A.H., 2017. Hydrothermal cooling of the ocean crust: Insights from ODP Hole 1256D. Earth and Planetary Science Letters 462, 110-121. doi:10.1016/j.eps1.2017.01.010

Hildenbrand, A., Madureira, P., Marques, F.O., Cruz, I., Henry, B., Silva, P., 2008. Multistage evolution of a sub-aerial volcanic ridge over the last $1.3 \mathrm{Myr}$ : S. Jorge Island, Azores Triple Junction. Earth and Planetary Science Letters 273, 289-298.

Hirschmann, M.M., Ghiorso, M.S., Wasylenki, L.E., Asimow, P.D., Stolper, E.M., 1998. Calculation of Peridotite Partial Melting from Thermodynamic Models of Minerals and Melts. I. Review of Methods and Comparison with Experiments. Journal of Petrology 39, 10911115 .

Hirschmann, M.M., Ghiorso, M.S., Stolper, E.M., 1999. Calculation of peridotite partial melting from thermodynamic models of minerals and melts; II, Isobaric variations in melts near the solidus and owing to variable source composition. Journal of Petrology 40, 297-313.

Hofmann, A.W., 1997. Mantle geochemistry: the message from oceanic volcanism. Nature $385,219-229$.

Hofmann, A.W., Jochum, K.P., Seufert, M., White, W.M., 1986. Nb and Pb in oceanic basalts: new constraints on mantle evolution. Earth and Planetary Science Letters 79, 33-45.

Hofmann, A.W., 2003. Sampling mantle heterogeneity through oceanic basalts: isotopes and trace elements, in: Carlson, R.W. (Ed.), Treatise on geochemistry. Elsevier, Amsterdam, pp. 61-101.

Horita, J., 2014. Oxygen and carbon isotope fractionation in the system dolomite-water-CO2 to elevated temperatures. Geochimica et Cosmochimica Acta 129, 111-124. doi:10.1016/j.gca.2013.12.027

Hübscher, C., Gohl, K., 2014. Reflection/Refraction Seismology. Springer, New York, NY.

Hübscher, C., Beier, C., Al-Hseinat, M., Batista, L., Blum, M., Bobsin, M., Bülow, J., Frahm, L., Grob, H., Hildenbrandt, A., Kalvelage, C., Kammann, J., Knevels, K., Levanos, I., 
Nomikou, P., Reichel, H., Petry, F., Spickermann, D., Stackemann, F., Stratmann, S., Terrinha, P., Vögele, M., Winter, S., Schaaf, T., Schleifer, B., Stelzner, M., Spitzy, A., Weinzierl, C., Weiß, B.J., 2016. Azores Plateau - Cruise No. M113/1 - December 29, 2014 January 22, 2015 - Ponta Delgada (Portugal) - Ponta Delgada (Portugal). , METEORBerichte. DFG-Senatskommission für Ozeanographie, p. 31. doi:10.2312/cr_m113_1

Ingle, S., Mahoney, J.J., Sato, H., Coffin, M.F., Kimura, J.-I., Hirano, N., Nakanishi, M., 2007. Depleted mantle wedge and sediment fingerprint in unusual basalts from the Manihiki Plateau, central Pacific Ocean. Geology 35, 595-598.

Johnson, J.S., Gibson, S.A., Thompson, R.N., Nowell, G.M., 2005. Volcanism in the Vitim Volcanic Field, Siberia: Geochemical Evidence for a Mantle Plume Beneath the Baikal Rift Zone. Journal of Petrology 46, 1309-1344. doi:10.1093/petrology/egi016

Kato, Y., Fujinaga, K., Nakamura, K., Takaya, Y., Kitamura, K., Ohta, J., Toda, R., Nakashima, T., Iwamori, H., 2011. Deep-sea mud in the Pacific Ocean as a potential resource for rare-earth elements. Nature Geoscience 4, 535. doi:10.1038/ngeo1185

Kerr, A.C., 2014. Oceanic Plateaus, in: Carlson, R.W. (Ed.), Treatise on Geochemistry 2nd Edition. Elsevier, Amsterdam, pp. 631-667.

Kodera, P., Lexa, J., Rankin, A., Fallick, A., 2005. Epithermal gold veins in a caldera setting: Banska Hodrusa, Slovakia. Mineralium Deposita 39, 921-943. doi:10.1007/s00126-004-04495

Korenaga, J., 2005. Why did not the Ontong Java Plateau form subaerially? Earth and Planetary Science Letters 234, 385-399.

Krause, D.C., Watkins, N.D., 1970. North Atlantic crustal genesis in the vicinity of the Azores. Geophysical Journal of the Royal Astronomical Society 19, 261-283.

Larrea, P., França, Z., Lago, M., Widom, E., Galé, C., Ubide, T., 2013. Magmatic Processes and the Role of Antecrysts in the Genesis of Corvo Island (Azores Archipelago, Portugal). Journal of Petrology 54, 769-793. doi:10.1093/petrology/egs084

Larrea, P., Galé, C., Ubide, T., Widom, E., Lago, M., França, Z., 2014. Magmatic Evolution of Graciosa (Azores, Portugal). Journal of Petrology 55, 2,125-122,154. doi:10.1093/petrology/egu052 
Larrea, P., França, Z., Widom, E., Lago, M., 2018. Petrology of the Azores Islands, in: Küppers, U., Beier, C. (Eds.), Volcanoes of the Azores. Springer Nature, Heidelberg.

Larson, R.L., Erba, E., 1999. Onset of the Mid-Cretaceous greenhouse in the BarremianAptian: Igneous events and the biological, sedimentary, and geochemical responses. Paleoceanography 14, 663-678. doi:10.1029/1999PA900040

Luis, J., Miranda, J., 2008. Reevaluation of magnetic chrons in the North Atlantic between $35^{\circ} \mathrm{N}$ and $47^{\circ} \mathrm{N}$ : Implications for the formation of the Azores Triple Junction and associated plateau. Journal of Geophysical Research 113, B10105. doi:10.1029/2007JB00557

Luis, J.F., Miranda, J.M., Galdeano, A., Patriat, P., Rossignol, J.C., Mendes Victor, L.A., 1994. The Azores triple junction evolution since 10 Ma from aeromagnetic survey of the MidAtlantic Ridge. Earth and Planetary Science Letters 125, 439-459.

Luis, J.F., Miranda, J.M., Galdeano, A., Patriat, P., 1998. Constraints on the structure of the Azores spreading center from gravity data. Marine Geophysical Researches 20, 157-170.

Lyubetskaya, T., Korenaga, J., 2007. Chemical composition of Earth's primitive mantle and its variance: 1. Method and results. Journal of Geophysical Research 112, B03211. doi:10.1029/2005JB004223

Mahoney, J.J., Spencer, K.J., 1991. Isotopic evidence for the origin of the Manihiki and Ontong Java oceanic plateaus. Earth and Planetary Science Letters 104, 196-210. doi:10.1016/0012-821X(91)90204-U

Mahoney, J.J., Storey, M., Duncan, R.A., Spencer, K.J., Pringle, M., 1993. Geochemistry and age of the Ontong Java Plateau, in: Pringle, M., Sager, W., W., S., Stein, S. (Eds.), The Mesozoic Pacific: Geology, Tectonics, and Volcanism. American Geophysical Union, pp. 233-261.

Mahoney, J.J., Jones, W.B., Frey, F.A., Salters, V.J.M., Pyle, D.G., Davies, H.L., 1995. Geochemical characteristics of lavas from Broken Ridge, the Naturaliste Plateau and southernmost Kerguelen Plateau: Cretaceous plateau volcanism in the southeast Indian Ocean. Chemical Geology 120, 315-345.

Marques, F.O., Catalão, J.C., DeMets, C., Costa, A.C.G., Hildenbrand, A., 2013. GPS and tectonic evidence for a diffuse plate boundary at the Azores Triple Junction. Earth and Planetary Science Letters 381, 177-187. doi:10.1016/j.epsl.2013.08.051 
Marques, F.O., Hildenbrand, A., Hübscher, C., 2018. Evolution of a volcanic island on the shoulder of an oceanic rift and geodynamic implications: S. Jorge Island on the Terceira Rift, Azores Triple Junction. Tectonophysics 738-739, 41-50. doi:10.1016/j.tecto.2018.05.012

McDonough, W.F., Sun, S.-S., 1995. The composition of the Earth. Chemical Geology 120, 223-253.

McKenzie, D., Bickle, M.J., 1988. The volume and composition of melt generated by extension of the lithosphere. Journal of Petrology 29, 625-679.

Metrich, N., Zanon, V., Creon, L., Hildenbrand, A., Moreira, M., Marques, F.O., 2014. Is the 'Azores Hotspot' a Wetspot? Insights from the Geochemistry of Fluid and Melt Inclusions in Olivine of Pico Basalts. Journal of Petrology 55, 377-393. doi:10.1093/Petrology/Egt071

Michael, P.J., 1999. Implications for magmatic processes at Ontong Java Plateau from volatile and major element contents of Cretaceous basalt glasses. Geochemistry Geophysics Geosystems 1. doi:10.1029/1999gc000025

Miranda, J.M., Luis, J.F., Lourenço, N., 2018. The Tectonic Evolution of the Azores Based on Magnetic Data, in: Küppers, U., Beier, C. (Eds.), Volcanoes of the Azores. Springer Nature, Heidelberg.

Neal, C.R., Mahoney, J.J., Kroenke, L.W., Duncan, R.A., Petterson, M.G., 1997. The Ontong Java Plateau, Large igneous provinces; continental, oceanic, and planetary flood volcanism. American Geophysical Union, Washington, DC, United States, pp. 183-216.

Neal, C.R., Mahoney, J.J., Chazey, W.J., III, 2002. Mantle sources and the highly variable role of continental lithosphere in basalt petrogenesis of the Kerguelen Plateau and Broken Ridge LIP; results from ODP Leg 183. Journal of Petrology 43, 1177-1205.

Neo, N., Yamazaki, S., Miyashita, S., 2009. Data report; whole-rock major and trace elements and mineral compositions of the sheeted dike-gabbro transition in ODP Hole 1256D. Proceedings of the Integrated Ocean Drilling Program 309, 1.

O’Neill, C., Sigloch, K., 2018. Crust and Mantle Structure Beneath the Azores HotspotEvidence from Geophysics, in: Küppers, U., Beier, C. (Eds.), Volcanoes of the Azores. Springer Nature, Heidelberg. 
Pfänder, J.A., Münker, C., Stracke, A., Mezger, K., 2007. Nb/Ta and Zr/Hf in ocean island basalts - Implications for crust-mantle differentiation and the fate of Niobium. Earth and Planetary Science Letters 254, 158-172. doi:10.1016/j.epsl.2006.11.027

Pin, C., Zalduegui, J.S., 1997. Sequential separation of light rare-earth elements, thorium and uranium by miniaturized extraction chromatography: Application to isotopic analyses of silicate rocks. Analytica Chimica Acta 339, 79-89. doi:10.1016/S0003-2670(96)00499-0

Richardson, C.J., Cann, J.R., Richards, H.G., Cowan, J.G., 1987. Metal-depleted root zones of the Troodos ore-forming hydrothermal systems, Cyprus. Earth and Planetary Science Letters 84, 243-253. doi:10.1016/0012-821X(87)90089-6

Ridley, V.A., Richards, M.A., 2010. Deep crustal structure beneath large igneous provinces and the petrologic evolution of flood basalts. Geochemistry, Geophysics, Geosystems 11.

Romer, R.H.W., Beier, C., Haase, K.M., Hübscher, C., 2018. Correlated Changes Between Volcanic Structures and Magma Composition in the Faial Volcanic System, Azores. Frontiers in Earth Science 6, 78.

Rose-Koga, E.F., Koga, K.T., Moreira, M., Vlastelic, I., Jackson, M.G., Whitehouse, M.J., Shimizu, N., Habib, N., 2017. Geochemical systematics of Pb isotopes, fluorine, and sulfur in melt inclusions from Sao Miguel, Azores. Chemical Geology 458, 22-37. doi:10.1016/j.chemgeo.2017.03.024

Rubin, K.H., Sinton, J.M., 2007. Inferences on mid-ocean ridge thermal and magmatic structure from MORB compositions. Earth and Planetary Science Letters 260, 257-276.

Rubin, K.H., Sinton, J.M., Maclennan, J., Hellebrand, E., 2009. Magmatic filtering of mantle compositions at mid-ocean-ridge volcanoes. Nature Geoscience 2, 321-328. doi:10.1038/Ngeo504

Sager, W.W., Sano, T., Geldmacher, J., 2016. Formation and evolution of Shatsky Rise oceanic plateau: Insights from IODP Expedition 324 and recent geophysical cruises. EarthScience Reviews 159, 306-336. doi:10.1016/j.earscirev.2016.05.011

Sano, T., Shimizu, K., Ishikawa, A., Senda, R., Chang, Q., Kimura, J.-I., Widdowson, M., Sager, W.W., 2012. Variety and origin of magmas on Shatsky Rise, northwest Pacific Ocean. Geochemistry, Geophysics, Geosystems 13, Q08010. doi:10.1029/2012GC004235 
Self, S., 2006. The effects and consequences of very large explosive volcanic eruptions. Philosophical Transactions of the Royal Society A: Mathematical, Physical and Engineering Sciences 364, 2073.

Self, S., Blake, S., 2008. Consequences of explosive supereruptions. Elements 4, 41-46. doi:10.2113/Gselements.4.1.41

Self, S., Blake, S., Sharma, K., Widdowson, M., Sephton, S., 2008. Sulfur and chlorine in Late Cretaceous Deccan magmas and eruptive gas release. Science 319, 1654-1657. doi:10.1126/science. 1152830

Sharkov, E., Bogina, M., Chistyakov, A., 2017. Magmatic systems of large continental igneous provinces. Geoscience Frontiers 8, 621-640. doi:10.1016/j.gsf.2016.03.006

Sharp, Z.D., Gibbons, J.A., Maltsev, O., Atudorei, V., Pack, A., Sengupta, S., Shock, E.L., Knauth, L.P., 2016. A calibration of the triple oxygen isotope fractionation in the $\mathrm{SiO} 2-\mathrm{H} 2 \mathrm{O}$ system and applications to natural samples. Geochimica et Cosmochimica Acta 186, 105-119. doi:10.1016/j.gca.2016.04.047

Sleep, N.H., 1992. Hotspot Volcanism and Mantle Plumes. Annual Review of Earth and Planetary Sciences 20, 19.

Staudigel, H., 2003. Hydrothermal alterations processes in the oceanic crust., in: Rudnick, R.L. (Ed.), Treatise on geochemistry. Elsevier, Amsterdam, pp. 511-535.

Stoll, B., Jochum, K.P., Herwig, K., Marghaleray, A., Flanz, M., Kreuzburg, B., Kuzmin, D.V., Willbold, M., Enzweiler, J., 2008. An automated Iridium-Strip Heater for LA-ICP-MS Bulk Analysis of Geological Samples. Geostandards and Geoanalytical Research 32, 5-26.

Stracke, A., Bourdon, B., 2009. The importance of melt extraction for tracing mantle heterogeneity. Geochimica et Cosmochimica Acta 73, 218-238. doi:10.1016/j.gca.2008.10.015

Sun, W., Hu, Y., Kamenetsky, V.S., Eggins, S.M., Chen, M., Arculus, R.J., 2008. Constancy of $\mathrm{Nb} / \mathrm{U}$ in the mantle revisited. Geochimica et Cosmochimica Acta 72, 3542-3549. 
Tarduno, J.A., Sliter, W.V., Kroenke, L., Leckie, M., Mayer, H., Mahoney, J.J., Musgrave, R., Storey, M., Winterer, E.L., 1991. Rapid Formation of Ontong Java Plateau by Aptian Mantle Plume Volcanism. Science 254, 399-403. doi:10.1126/science.254.5030.399

Teagle, D.A.H., Bickle, M.J., Alt, J.C., 2003. Recharge flux to ocean-ridge black smoker systems: a geochemical estimate from ODP Hole 504B. Earth and Planetary Science Letters 210, 81-89. doi:10.1016/S0012-821x(03)00126-2

Tejada, M.L.G., Ravizza, G., Suzuki, K., Paquay, F.S., 2012. An extraterrestrial trigger for the Early Cretaceous massive volcanism? Evidence from the paleo-Tethys Ocean. Scientific Reports 2, 268. doi:10.1038/srep00268

Tejada, M.L.G., Geldmacher, J., Hauff, F., Heaton, D., Koppers, A.A.P., Garbe-Schönberg, D., Hoernle, K., Heydolph, K., Sager, W.W., 2016. Geochemistry and age of Shatsky, Hess, and Ojin Rise seamounts: Implications for a connection between the Shatsky and Hess Rises. Geochimica et Cosmochimica Acta 185, 302-327. doi:10.1016/j.gca.2016.04.006

Turner, S., Hawkesworth, C., Rogers, N., King, P., 1997. U-Th isotope disequilibria and ocean island basalt generation in the Azores. Chemical Geology 139, 145-164.

Van Achterbergh, E., Ryan, C.G., Jackson, S.E., Griffin, W.L., 2001. Data reduction software for LA-ICP-MS: appendix, in: Sylvester, P.J. (Ed.), Laser Ablation-ICPMass Spectrometry in the Earth Sciences: Principles and Applications. Mineralogical Association of Canada (MAC) Short Course Series, Ottawa, pp. 239-243.

Vogt, P.R., Jung, W.Y., 2004. The Terceira Rift as hyper-slow, hotspot-dominated oblique spreading axis: A comparison with other slow-spreading plate boundaries. Earth and Planetary Science Letters 218, 77-90. doi:10.1016/S0012-821X(03)00627-7

Vogt, P.R., Jung, W.-Y., 2018. The "Azores Geosyndrome" and Plate Tectonics: Research History, Synthesis, and Unsolved Puzzles, in: Küppers, U., Beier, C. (Eds.), Volcanoes of the Azores. Springer Nature, Heidelberg.

Weis, D., Kieffer, B., Maerschalk, C., Barling, J., de Jong, J., Williams, G.A., Hanano, D., Pretorius, W., Mattielli, N., Scoates, J.S., Goolaerts, A., Friedman, R.M., Mahoney, J.B., 2006. High-precision isotopic characterization of USGS reference materials by TIMS and MC-ICP-MS. Geochemistry Geophysics Geosystems 7, Q08006. doi:10.1029/2006GC001283 
Weiß, B.J., Hübscher, C., Lüdmann, T., 2015. The tectonic evolution of the southeastern Terceira Rift/São Miguel region (Azores). Tectonophysics 654, 75-95. doi:10.1016/j.tecto.2015.04.018

Yang, T., Shen, Y., van der Lee, S., Solomon, S.C., Hung, S.-H., 2006. Upper mantle structure beneath the Azores hotspot from finite-frequency seismic tomography. Earth and Planetary Science Letters 250, 11-26. doi:10.1016/j.epsl.2006.07.031

Zanon, V., Frezzotti, M.L., 2013. Magma storage and ascent conditions beneath Pico and Faial islands (Azores archipelago): A study on fluid inclusions. Geochemistry Geophysics Geosystems 14, 3,494-493,514. doi:10.1002/Ggge.20221

Zanon, V., Küppers, U., Pacheco, J.M., Cruz, I., 2013. Volcanism from fissure zones and the Caldeira central volcano of Faial Island, Azores archipelago: geochemical processes in multiple feeding systems. Geological Magazine, 1-20. doi:10.1017/S0016756812000702

Zheng, Y.-F., 1993. Calculation of oxygen isotope fractionation in hydroxyl-bearing silicates. Earth and Planetary Science Letters 120, 247-263. doi:10.1016/0012-821X(93)90243-3

\section{Figure CAPTIONS:}

Fig. 1. a) Overview map of the Azores Plateau and Princessa Alice bank including sampling track of dives 810_ROV and 824_ROV of ROV Quest 4000m from MARUM. Samples marked are from RV Meteor cruises M113 (Hübscher et al., 2016), M128 (Beier et al., 2018a), and RV Poseidon cruises POS286 (Haase et al., 2002) and POS232 published in Beier et al. (2015) and Romer et al. (2018). Subaerial samples are discussed in detail in Beier et al. (2012) and Romer et al. (2018). Red square marks sampling area of this work.

Fig. 2. Seismic profile \#67 sampled through the profile during M113 (Hübscher et al., 2016). Green labels marked PS denote sedimentary units, units marked in red (P) are igneous units as interpreted from the seismic imaging. Red lines mark clear reflectors that can be used for relative age constraints. Border between PS1 and P1 cannot clearly be determined. ROV sampling images taken during M128 (Beier et al., 2018a).

Fig. 3. Representative thin section and electron microprobe images of the Princessa Alice bank lavas. For detailed description see main text.

Fig. 4. a) Observed and b) calculated modal mineralogical composition for all samples from bottom (left) to top. Illite and other clay phases have been summarized as "clay- 
minerals". Calculations in b) were performed with a least squares model using the major element XRF data.

Fig. 5. a) $\mathrm{SiO}_{2}$, b) $\mathrm{TiO}_{2}$, c) $\mathrm{Al}_{2} \mathrm{O}_{3}$, d) $\mathrm{Fe}_{2} \mathrm{O}_{3}{ }^{\mathrm{T}}$, e) $\mathrm{CaO}$, f) $\mathrm{Na}_{2} \mathrm{O}$, g) $\mathrm{K}_{2} \mathrm{O}$, and h) calculated $\mathrm{H}_{2} \mathrm{O}$ versus $\mathrm{MgO}\left(\mathrm{H}_{2} \mathrm{O}=\mathrm{LOI}-\mathrm{CO}_{2}\right)$; i) $\mathrm{CaO}$ versus $\mathrm{CO}_{2}$ contents of the southwestern Princessa Alice bank lava, from published Princessa Alice bank samples (Beier et al., 2015; Romer et al., 2018 ) and Faial and Pico island for comparison (Beier et al., 2012; Elliott et al., 2007; Metrich et al., 2014 ; Romer et al., 2018 ; Turner et al., 1997; Zanon and Frezzotti, 2013; Zanon et al., 2013). The samples are grouped according to their geographical distribution. Note that sample IEAZO1124 contains a large quartz vein resulting in the elevated $\mathrm{SiO}_{2}$ contents (Fig. 5a). Water and $\mathrm{CO}_{2}$ contents for Pico in h) and i) are from Metrich et al. (2014). Arrows mark trends of fractional crystallisation commonly observed on the Azores islands (Beier et al., 2006; Larrea et al., 2018).

Fig. 6. a) Primitive mantle normalized trace element abundance diagram. Primitive mantle from Lyubetskaya and Korenaga (2007), b) chondrite normalized Rare Earth Element (REE) diagram. Data sources as in Figure 5 except for anomalous HREE concentrations from melt inclusions from Metrich et al. (2014).

Fig. 7. a) $\mathrm{Nb} / \mathrm{Zr}$, b) $\mathrm{Tb} / \mathrm{Yb}$ versus $\mathrm{La} / \mathrm{Yb}$ c) $\mathrm{Nb} / \mathrm{U}$ versus $\mathrm{Ce} / \mathrm{Pb}$ and d) chondrite normalized $(\mathrm{Ce} / \mathrm{Yb})_{\mathrm{N}}$ e) $\mathrm{Ti} / \mathrm{Sm}$ and $\left.\mathrm{f}\right) \mathrm{Ti} / \mathrm{Yb}$ versus $\mathrm{TiO}_{2}$ contents. Model in b) from Beier et al. (2018b) shown for comparison. Samples in d-f) are only samples with $\mathrm{MgO}>4$ wt.\%. Chondrite from McDonough and Sun (1995). Data sources as in Figure 5 except for anomalous HREE concentrations from melt inclusions from Metrich et al. (2014). Field ins c) are range for oceanic basalts proposed by Hofmann et al. (1986)

Fig. 8. a) ${ }^{87} \mathrm{Sr} /{ }^{86} \mathrm{Sr}$ versus $\mathrm{MgO}$, b) $1 / \mathrm{Sr}$ and c) $\mathrm{Nd} / \mathrm{Sr}$ versus ${ }^{87} \mathrm{Sr} /{ }^{86} \mathrm{Sr}$ of the Azores lavas (note that sample IEAZO1167 has a Nd/Sr ratio of 2.02 not shown here). Seawater mixing curve in b) calculated from Goldstein and Jacobsen (1987) using a ${ }^{87} \mathrm{Sr} /{ }^{86} \mathrm{Sr}$ isotope ratio of 0.7091 (Burke et al., 1982). $\mathrm{Nd} / \mathrm{Sr}$ ratios of seawater tend towards $\sim 0$ due to extremely low concentrations of Nd (Goldstein and Jacobsen, 1987).

Fig. 9. Elevation of Western Princessa Alice bank samples versus a) $\mathrm{CaO}$ contents b), calculated $\mathrm{H}_{2} \mathrm{O}$ contents, c) $\mathrm{Pb}$ concentrations d) $\mathrm{Sr}$ concentrations, e) ${ }^{87} \mathrm{Sr} /{ }^{86} \mathrm{Sr}$ of whole rocks and mineral separates, f) $\delta^{18} \mathrm{O}_{\mathrm{V}-\mathrm{SmOW}}$ of mineral separates, g) temperatures calculated using $\delta^{18} \mathrm{O}_{\mathrm{V} \text {-SMOW }}$ and $\mathrm{h}$ ) water/rock ratios. Fields for 504B and 1256D in a) and e) are from Neo et al. (2009), Harris et al. (2015) and Bach et al. (2003). Epidote leachates in e) were analysed after leaching with concentrated HF and 
$\mathrm{HNO}_{3}$ acid. Temperatures were calculated from $\delta^{18} \mathrm{O}_{\mathrm{V} \text {-SMOw }}$ Water rock ratios were determined using approach described in Albarède et al. (1981) and calibration values from Zheng (1993), Horita (2014) and Sharp et al. (2016) for epidote, calcite and quartz, respectively. Best fit curve follows a logarithmic function ( $\mathrm{f}=-2324+190.471$ $\mathrm{x} \ln (\mathrm{x}))$. Exposition ages are from ${ }^{87} \mathrm{Sr} /{ }^{86} \mathrm{Sr}$ isotope ratios of carbonate crusts and were determined following the approach of Farrell et al. (1995). Underlined exposition age were determined based on occurrence of Globorotalia truncatulinoides and Globorotalia hirsute in a carbonate vein of sample IEAZO1120. Note that these are all minimum ages. Data sources for Azores islands are those from Figure 5.

\section{TABLE HEAdings:}

Table 1. Comprehensive whole rock major element, trace element and $\mathrm{Sr}-\mathrm{O}$ isotope dataset for the Princessa Alice Bank profile. Standard and minerals are available in supplemental Tables 1 to 3, respectively. $\mathrm{H}_{2} \mathrm{O}$ [wt.\%] = LOI $-\mathrm{CO}_{2}$ [wt.\%], Totals are major elements and loss on ignition (LOI) excluding $\mathrm{CO}_{2}$ and $\mathrm{H}_{2} \mathrm{O}$. Methods as described in the main text. International Geo Sample Numbers (IGSN) registered at System for Earth Sample Registration (SESAR, http://geosamples.org).

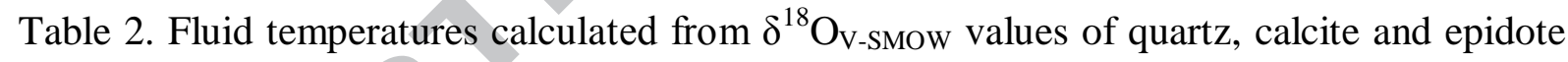
calculated from mineral separates using 1) Horita (2014), 2) Zheng (1993), and 3) Sharp et al. (2016). 


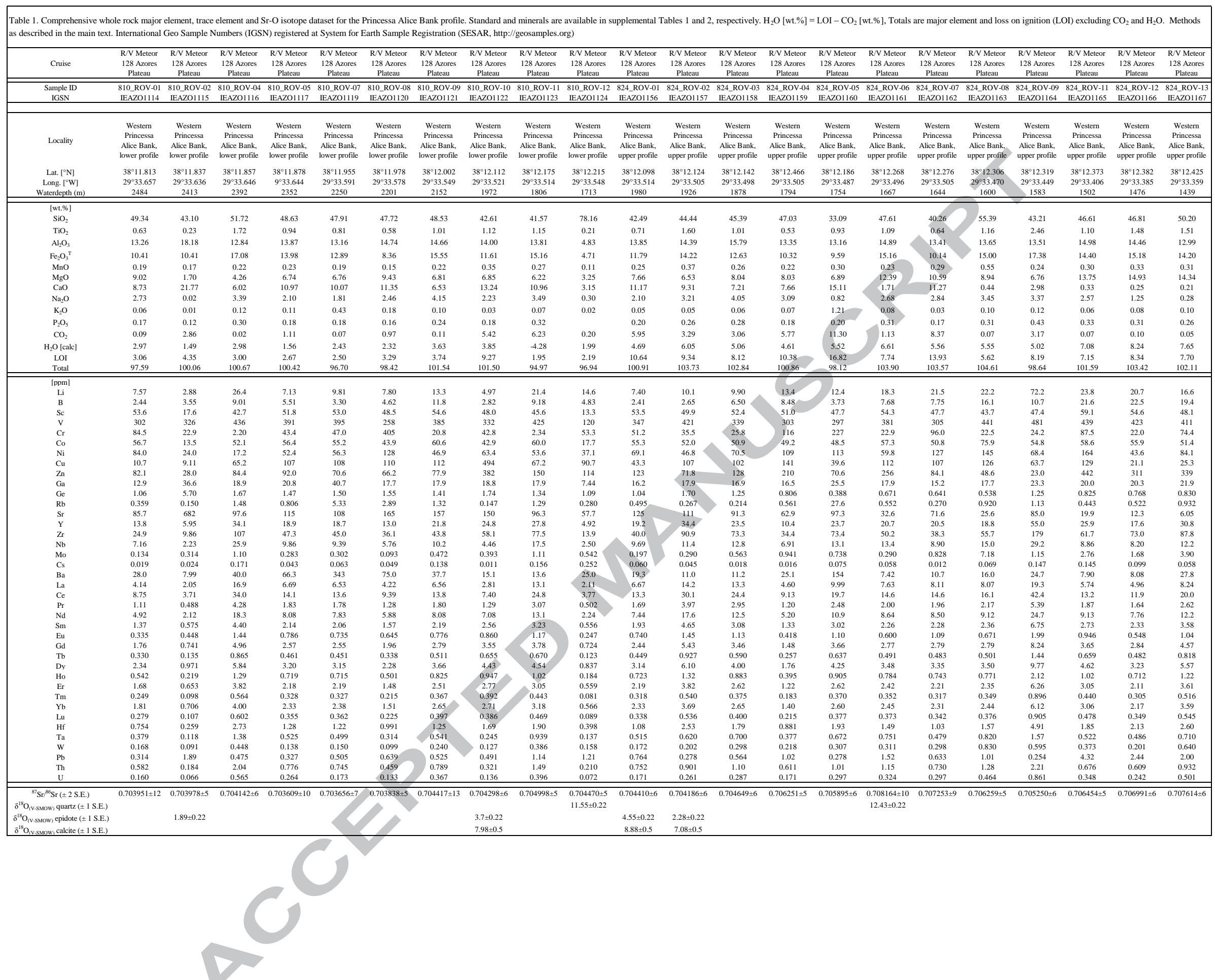


Table 2. Fluid temperatures calculated from $\delta^{18} \mathrm{O}_{\mathrm{V} \text {-SMOw }}$ values of quartz, calcite and epidote ca using 1) Horita (2014), 2) Zheng (1993), and 3) Sharp et al. (2016).

\begin{tabular}{|c|c|c|c|c|c|}
\hline IGSN & Sample & $\begin{array}{c}\text { Waterdepth } \\
{[\mathrm{m}]}\end{array}$ & Mineral analysed & $\delta^{18} \mathrm{O}_{(\mathrm{V}-\mathrm{SMOW})}$ & $\begin{array}{c}\text { T (Fluid }=0 \% \text { \%o) } \\
{\left[{ }^{\circ} \mathrm{C}\right]}\end{array}$ \\
\hline IEAZO1161 & 824_ROV-06 & 1667 & Quartz $^{* 3}$ & 12.4 & 190 \\
\hline IEAZO1124 & 810_ROV-12 & 1713 & Quartz $^{*}{ }^{3}$ & 11.6 & 203 \\
\hline \multirow{2}{*}{ IEAZO1157 } & \multirow{2}{*}{ 824_ROV-02 } & \multirow{2}{*}{1926} & Calcite $^{* 1}$ & 7.08 & 256 \\
\hline & & & Epidote $^{* 2}$ & 2.28 & 246 \\
\hline \multirow{2}{*}{\multicolumn{2}{|c|}{ IEAZO1122 810_ROV-10 }} & \multirow{2}{*}{1972} & Calcite $^{* 1}$ & 7.98 & 233 \\
\hline & & & Epidote $^{* 2}$ & 3.70 & 204 \\
\hline \multirow{2}{*}{\multicolumn{2}{|c|}{ IEAZO1156 824_ROV-01 }} & \multirow{2}{*}{1980} & Calcite $^{* 1}$ & 8.88 & 214 \\
\hline & & & Epidote $*^{2}$ & 4.50 & 186 \\
\hline IEAZO1115 & 810_ROV-02 & 2413 & Epidote $^{* 2}$ & 1.89 & 260 \\
\hline
\end{tabular}




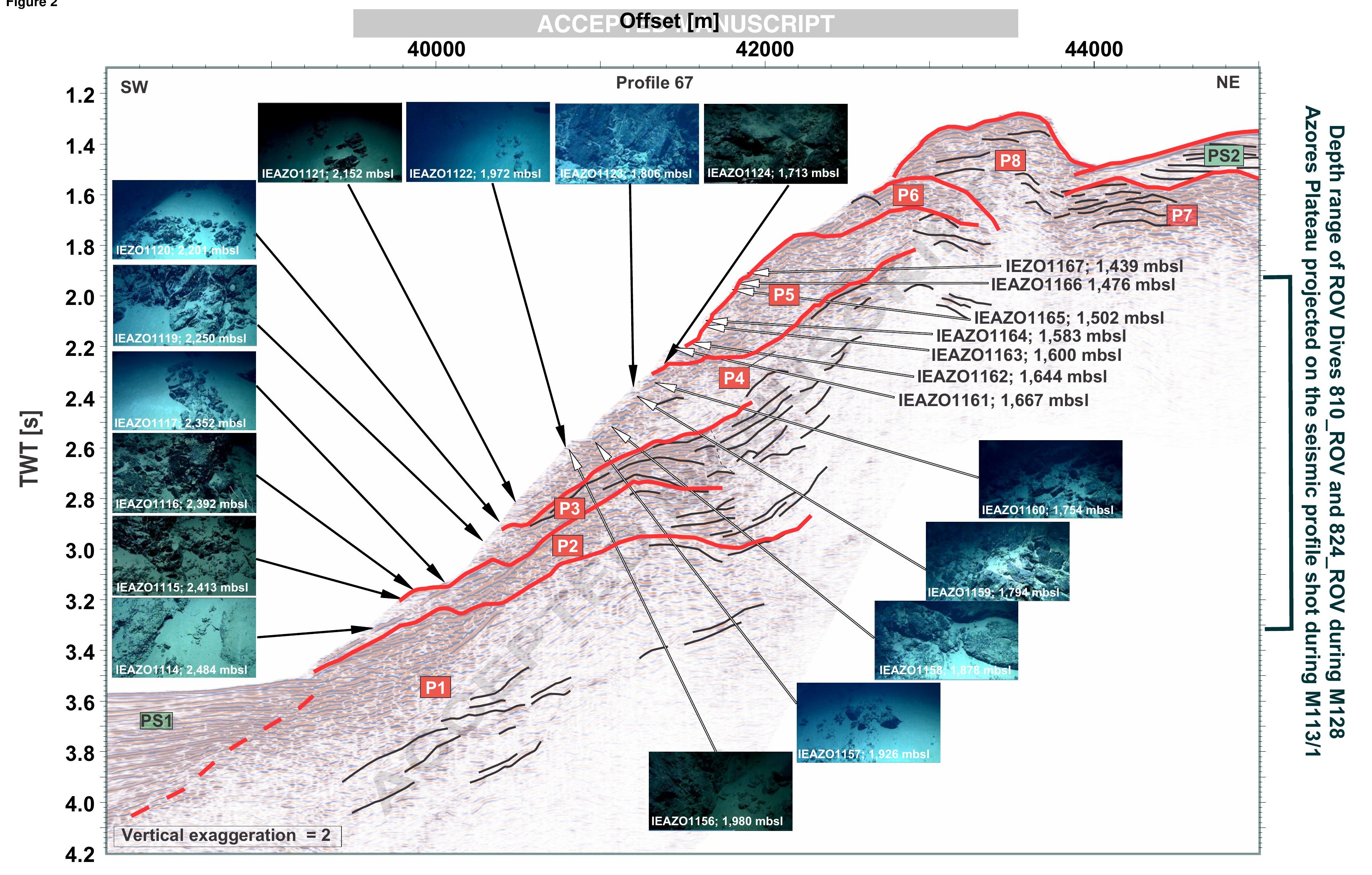


(a) Observed modal composition of western Princessa Alice bank

$$
\text { : }
$$

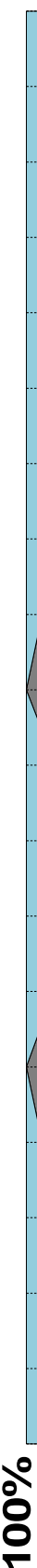
samples

Top

IEAZO1167 (824_ROV-13); 1,439 mbsI IEAZO1166 (824_ROV-12); 1,476 mbsI IEAZO1165 (824_ROV-11); 1,502 mbsI IEAZO1164 (824_ROV-09); 1,583 mbsI IEAZO1163 (824_ROV-08); 1,600 mbsI IEAZO1162 (824_ROV-07); 1,644 mbsI IEAZO1161 (824_ROV-06); 1,667 mbsI IEAZO1124 (810_ROV-12); 1,713 mbsI IEAZO1160 (824_ROV-05); 1,754 mbsI IEAZO1159 (824_ROV-04); 1,794 mbsI IEAZO1123 (810_ROV-11); 1,806 mbsI IEAZO1157 (824_ROV-02); 1,926 mbsI IEAZO1122 (810_ROV-10); 1,972 mbsI IEAZO1156 (824_ROV-01); 1,980 mbsI IEAZO1120 (810_ROV-08); 2,201 mbsI IEAZO1117 (810_ROV-05); 2,352 mbsI IEAZO1116 (810_ROV-04); 2,392 mbsI IEAZO1115 (810_ROV-02); 2,413 mbsI IEAZO1114 (810_ROV-01); 2,484 mbsI

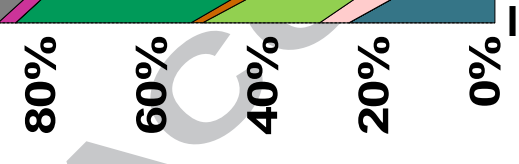

\section{Bottom} IEAZO1158 (824_ROV-03); 1,926 mbsI (b) Least squares model of modal composition of western Princessa Alice bank samples

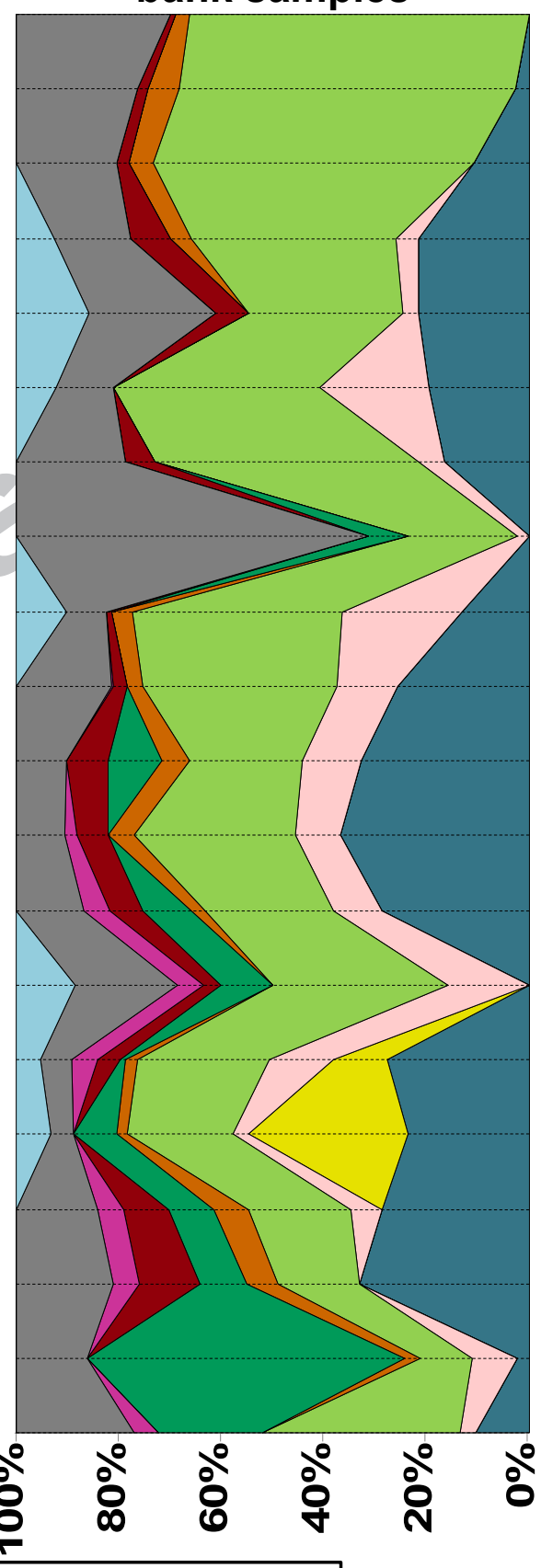

$\square$ Calcite Plagioclase 

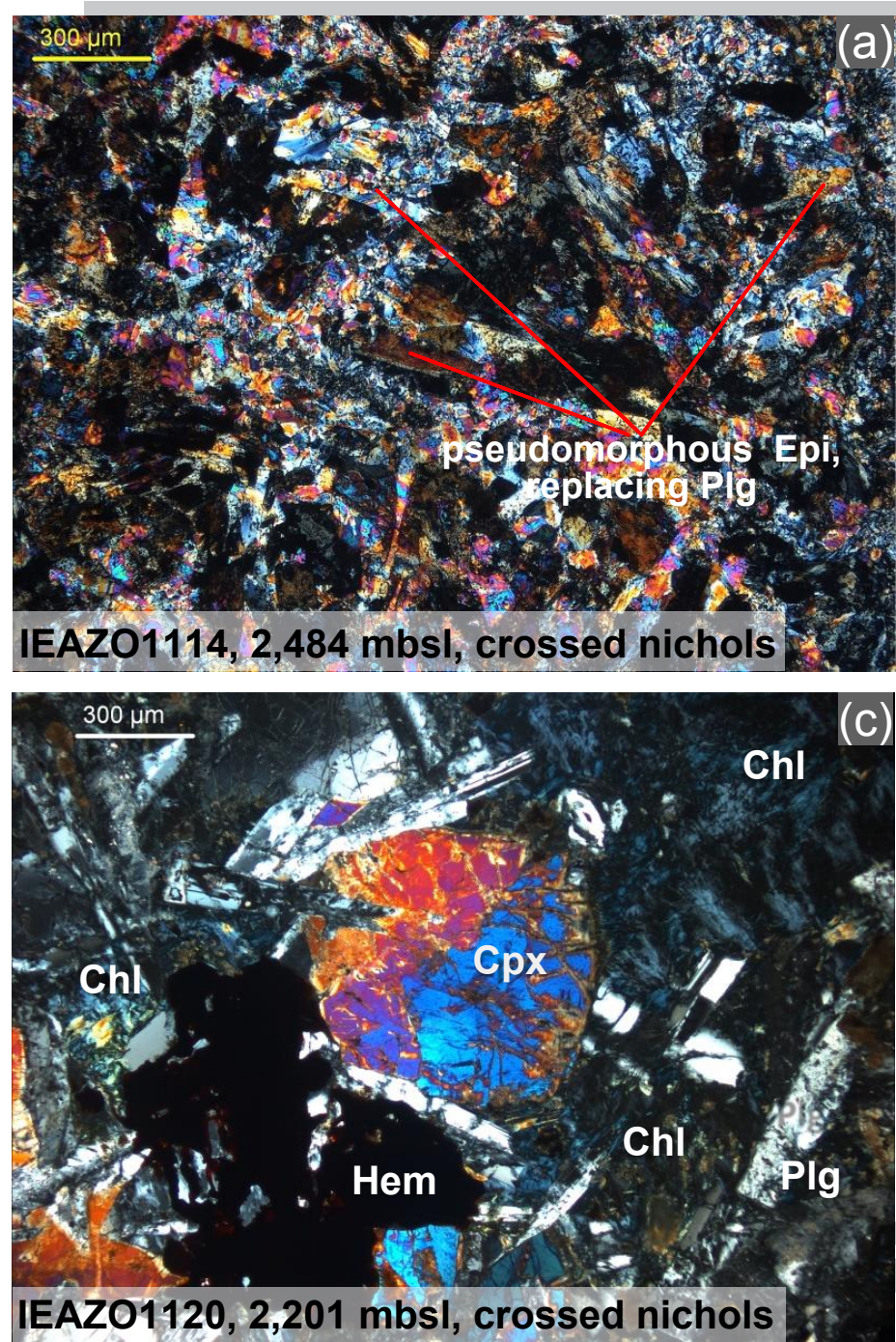

IEAZO1120, 2,201 mbsI, BSE
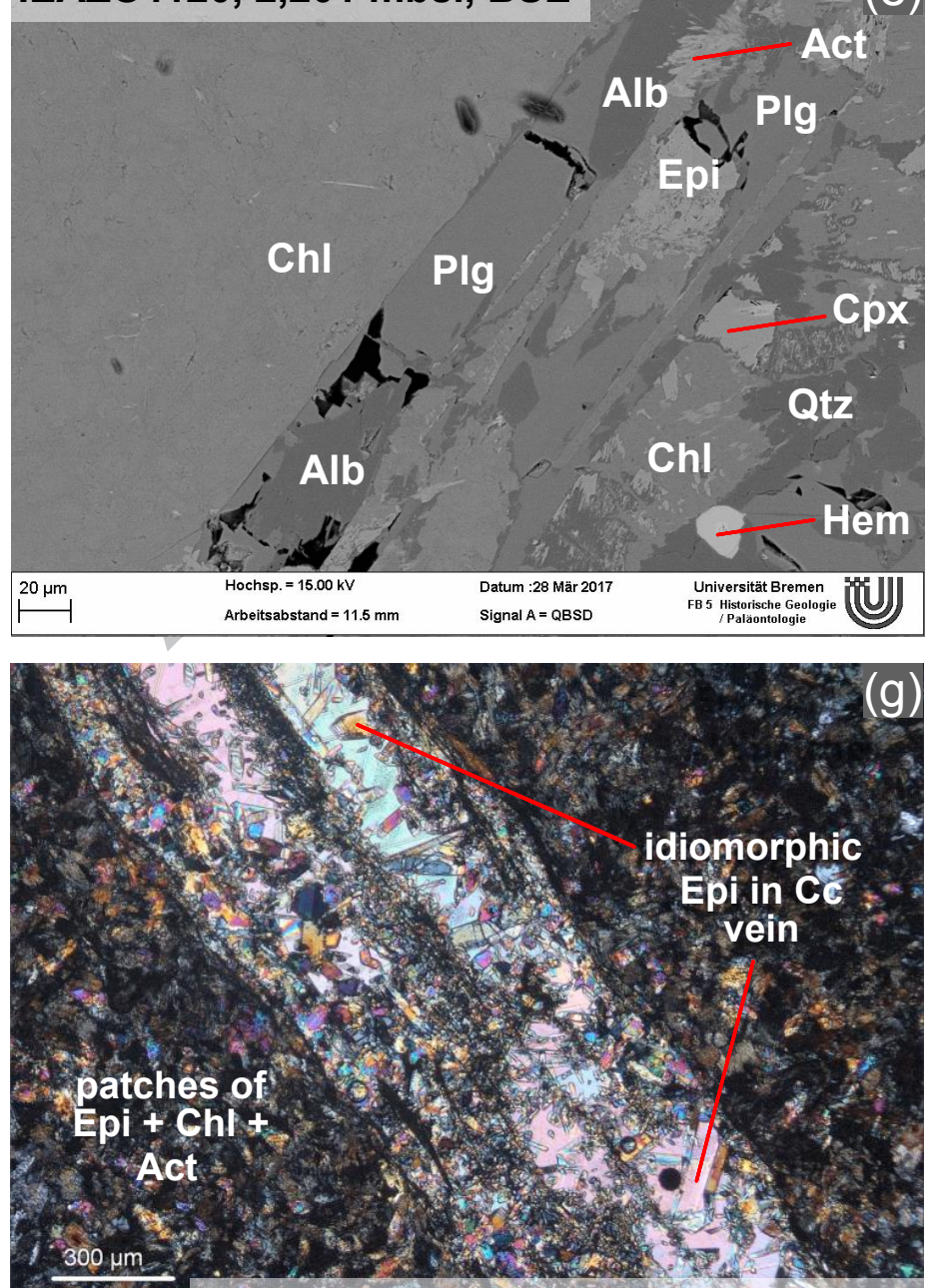

IEAZO1157, 1,926 mbsl, crossed nichols

e)

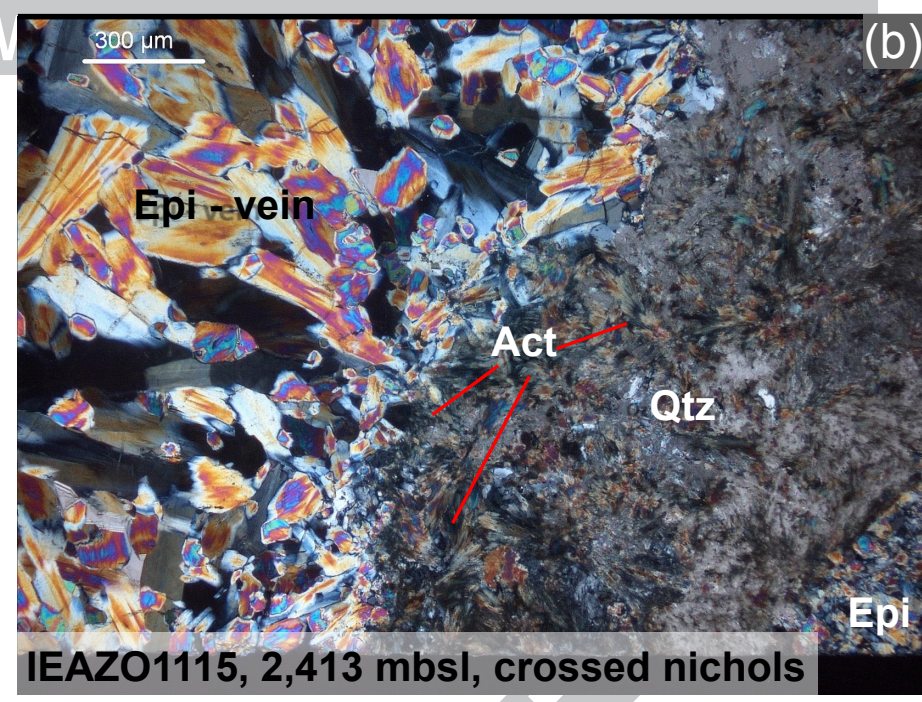

(b)
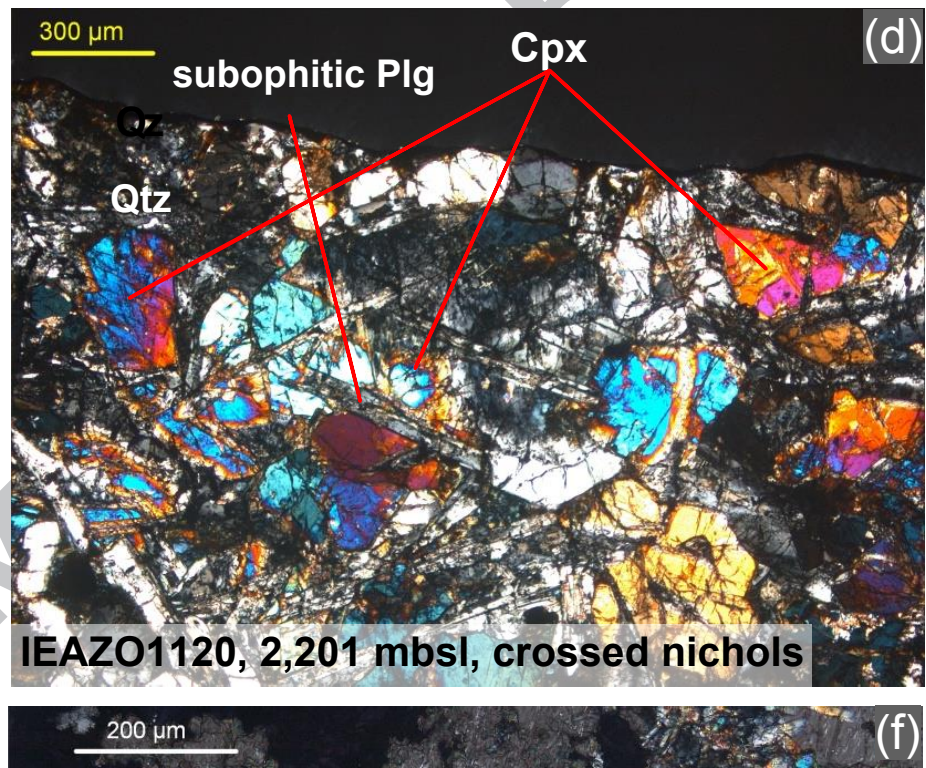

3. (f)

Chl $\rightarrow$ idiomorphic

Epi
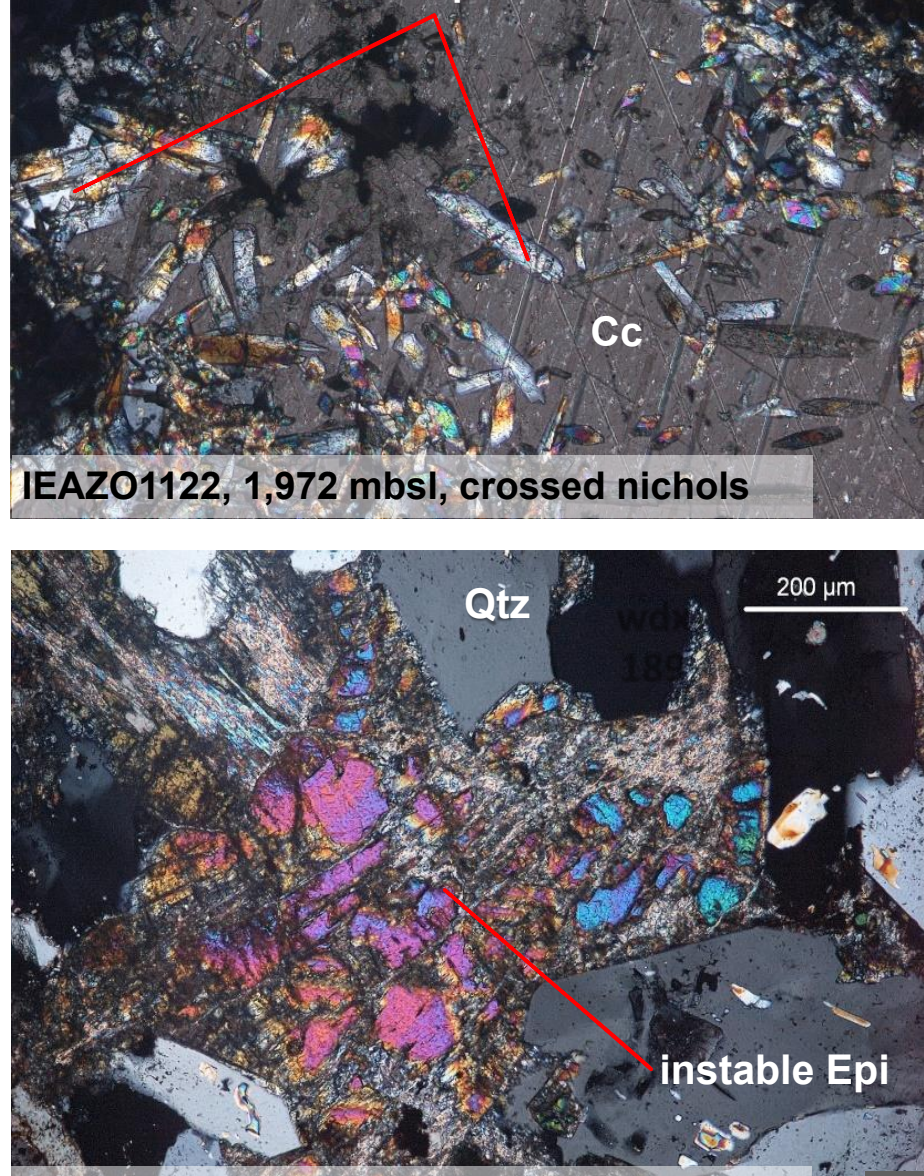

IEAZO1160, 1,754 mbsl, crossed nichols 

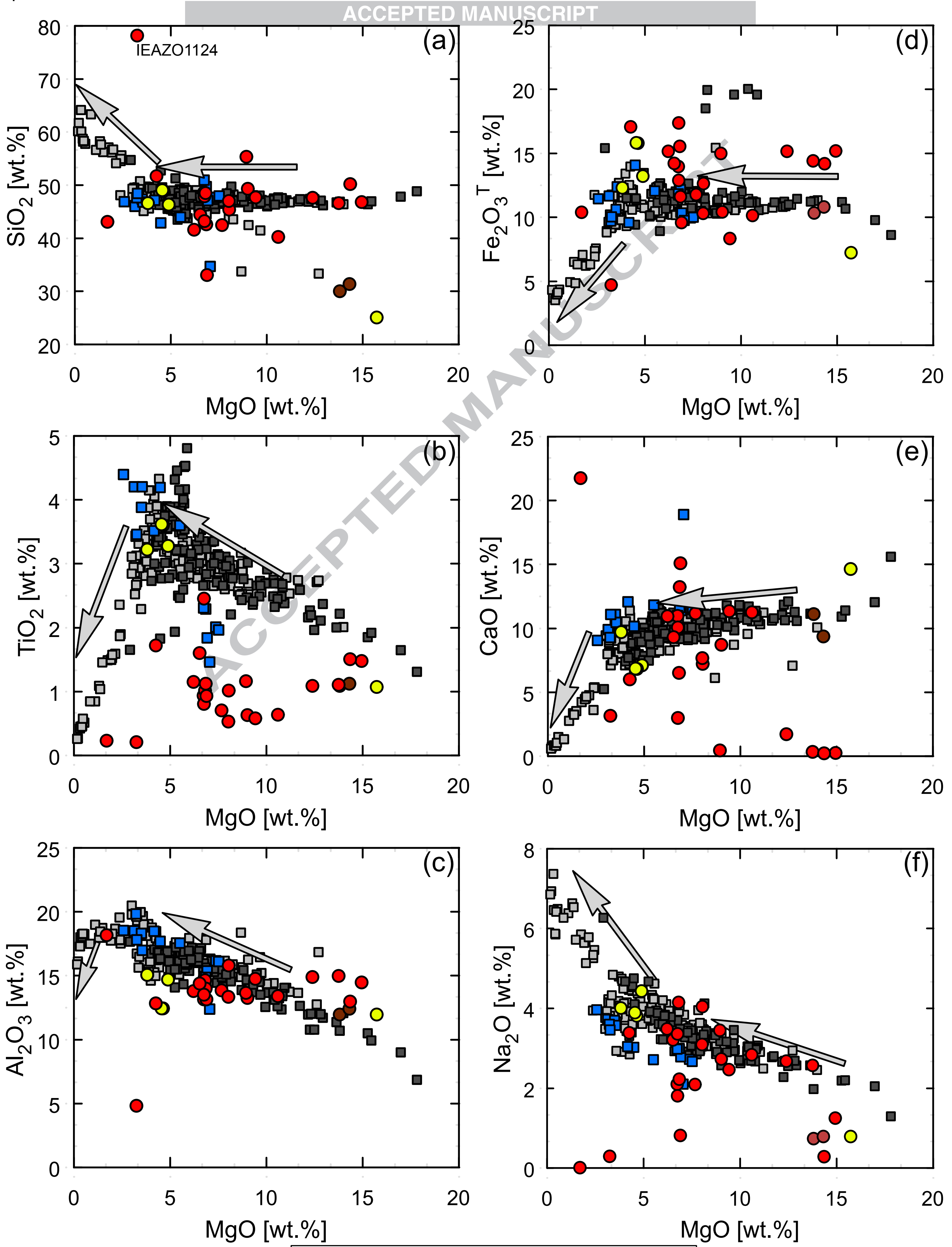

F Faial published
Pico published
Condor rift published
E Eastern Princessa Alice bank published
Western Princessa Alice bank published
Western Princessa Alice bank this work



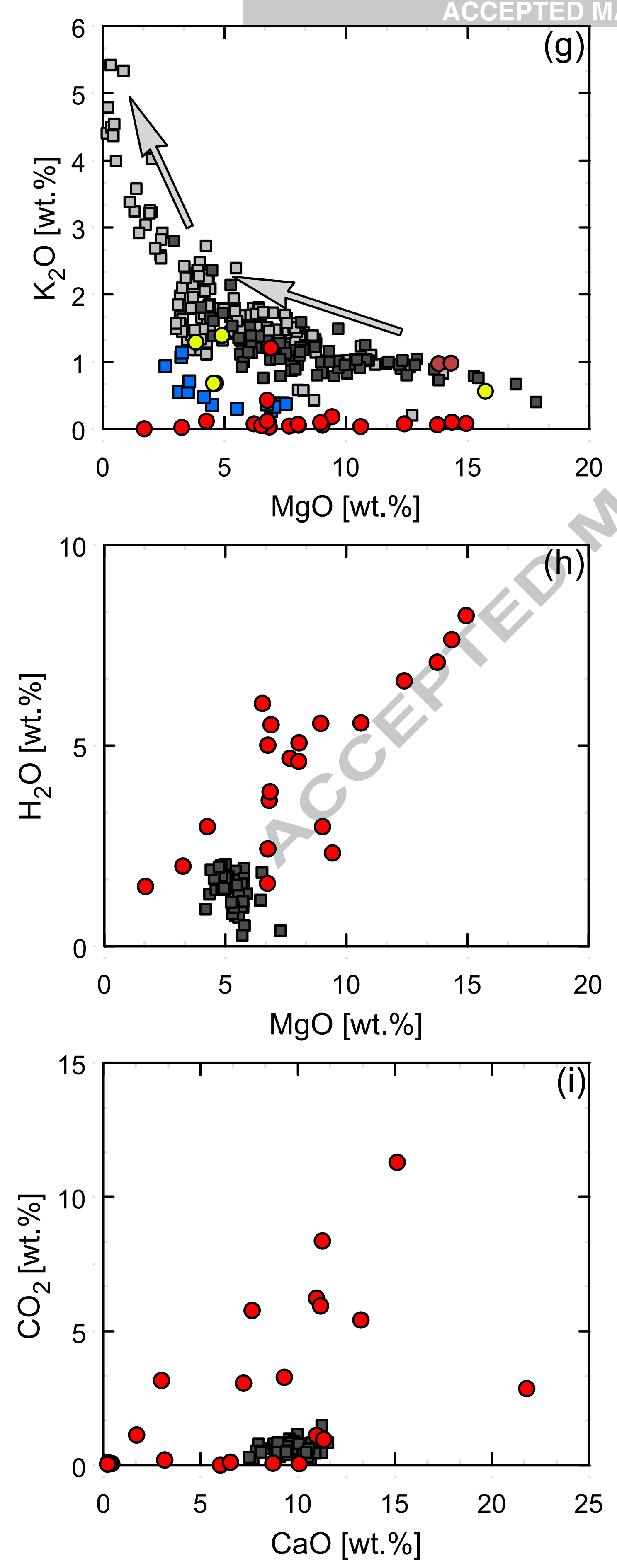
Figure 7
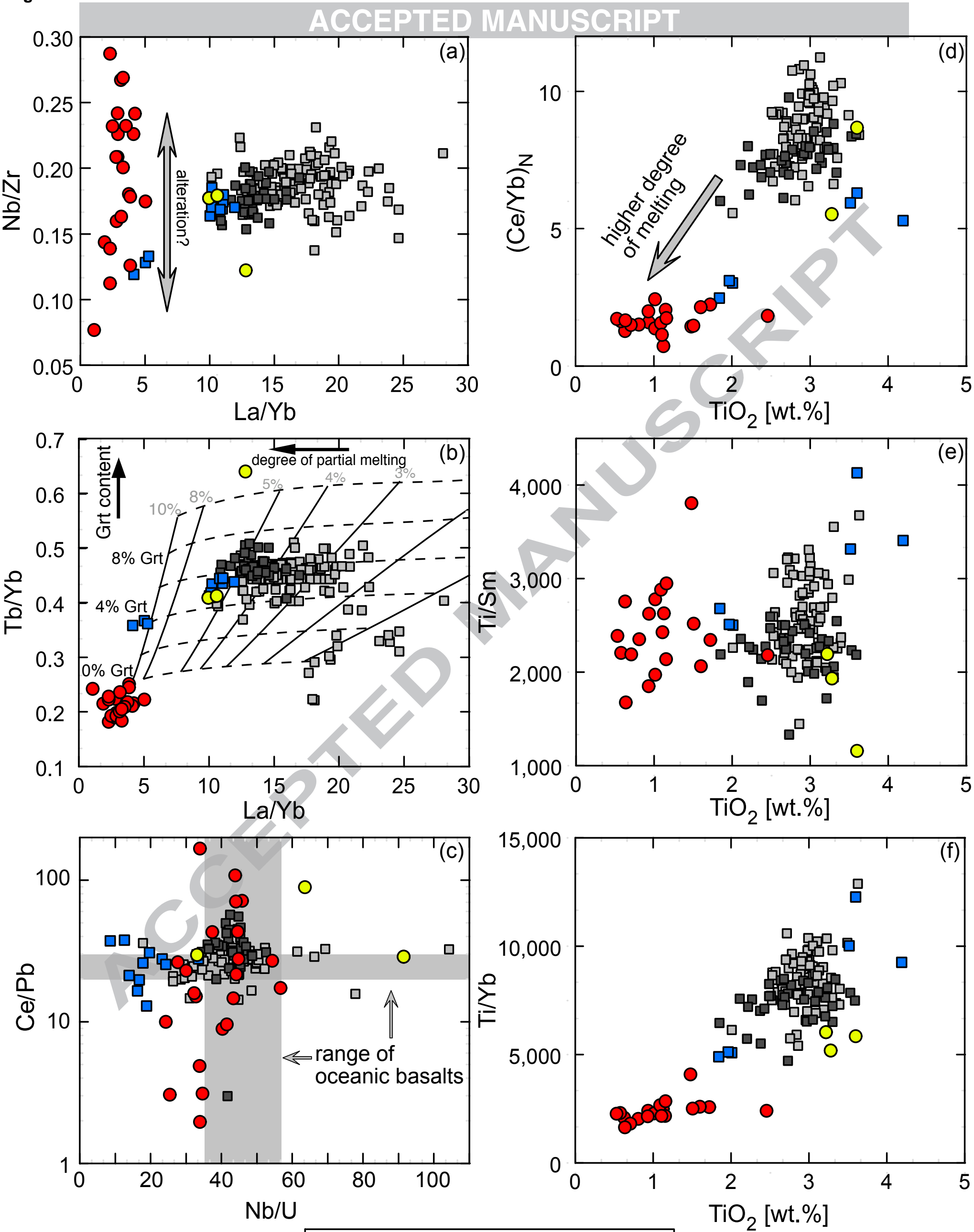

\begin{tabular}{|ll|}
\hline$\square$ & Faial published \\
$\square$ & Pico published \\
$\square$ & Condor rift published \\
$\bigcirc$ & Eastern Princessa Alice bank published \\
$\bigcirc$ & Western Princessa Alice bank this work \\
\hline
\end{tabular}



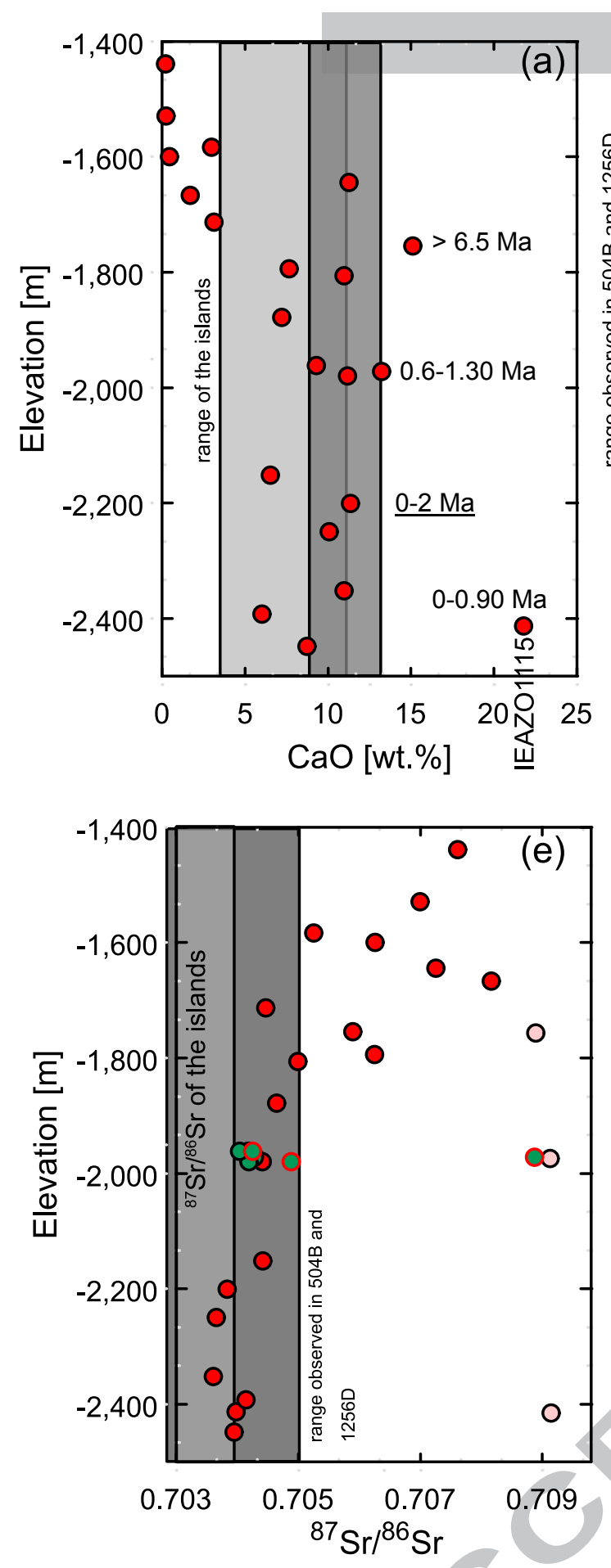

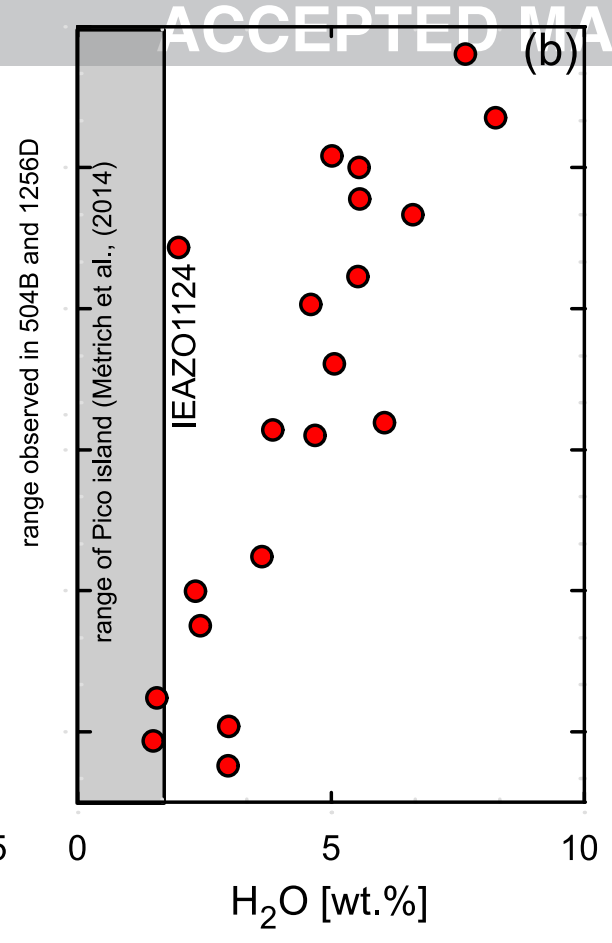

$\mathrm{H}_{2} \mathrm{O}$ [wt.\%]

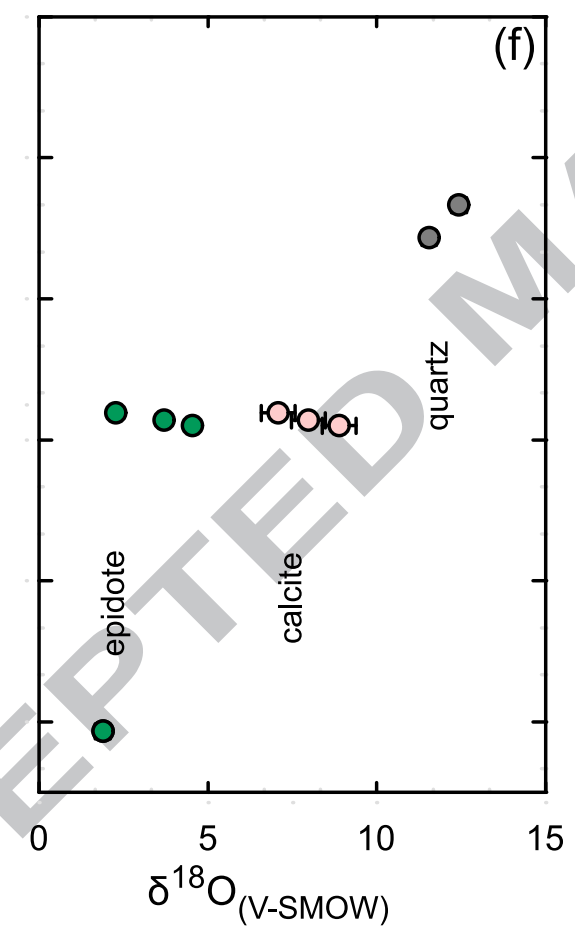

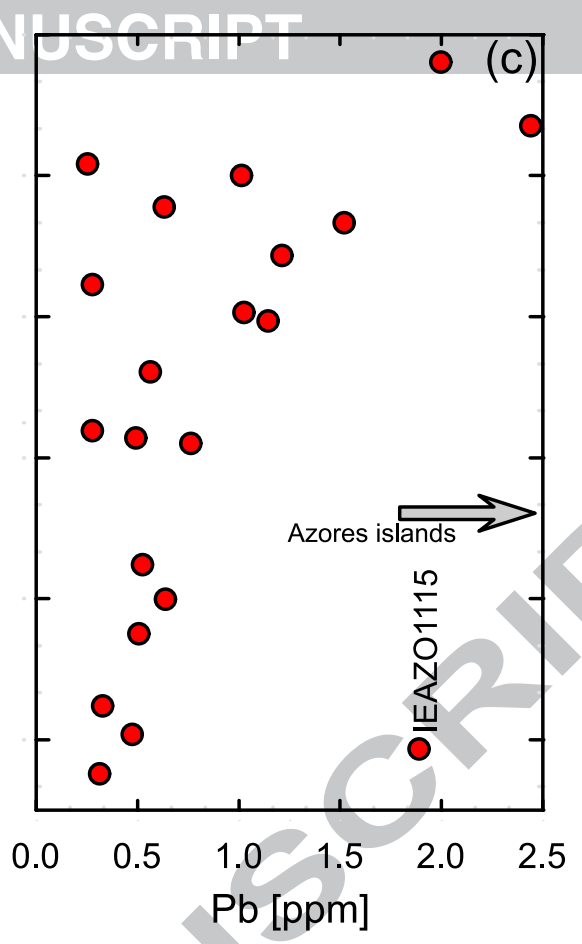
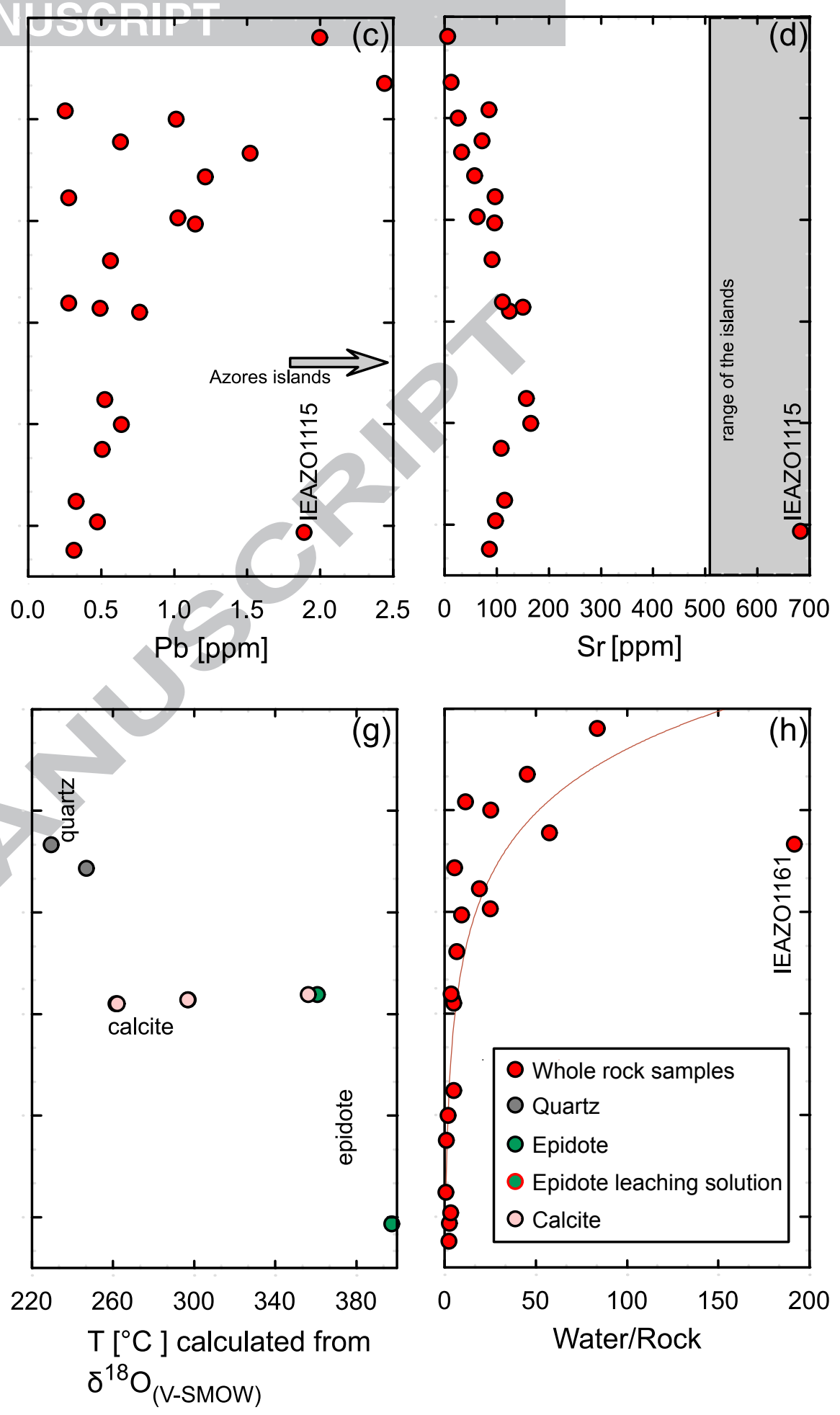

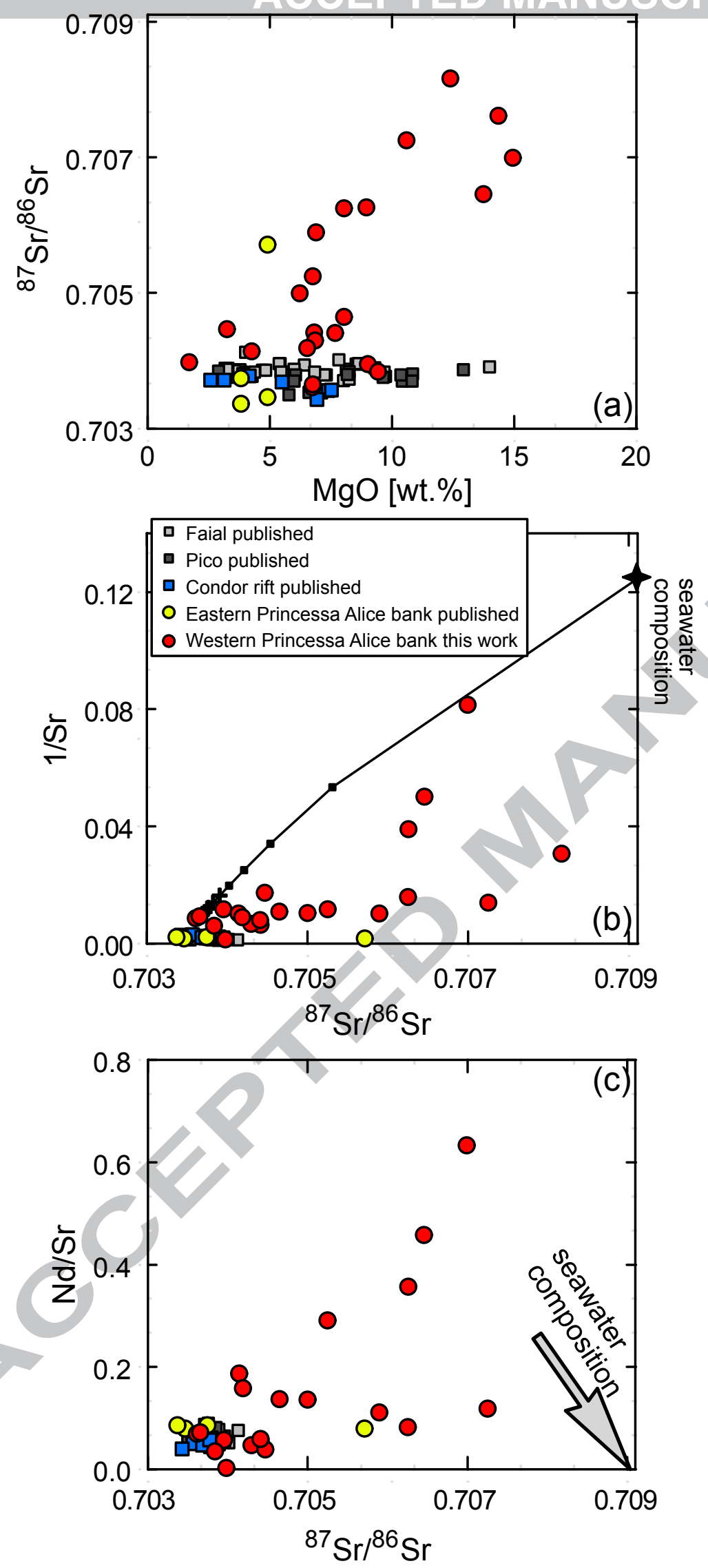